\title{
EL LLAMADO CONTRATO DE PRENDA SIN DESPLAZAMIENTO*
}

\section{THE SO-CALLED TRANSFER-BARRED PLEDGE CONTRACT}

Alejandro Guzmán Brito

\section{RESUMEN}

En la nueva regulación de la prenda sin desplazamiento, contenida en la ley $\mathrm{N}^{\circ} 20.190$, se distingue, como ejes, un contrato de prenda y un derecho real de prenda. El presente trabajo examina la normativa dispuesta para el contrato; e intenta fijar su naturaleza contractual o meramente convencional, sus caracteres y, en especial, su carácter solemne lo mismo que sus demás requisitos, los efectos que produce, su extinción y los convenios tipificados por la ley, como posibles de añadir a él.

Palabras clave: Prenda sin desplazamiento, contrato de prenda sin desplazamiento, solemnidades del contrato de prenda sin desplazamiento, convenios accesorios al contrato de prenda sin desplazamiento.

\section{AbSTRACT}

The new regulation of non-possessory pledge, contained in Law $\mathrm{N}^{\circ} 20,190$, is distinguished, as axes, a security agreement and a real right of pledge. This paper examines the rules set for the contract and try to fix their contractual nature or merely conventional, its characters and, in particular, its solemn character like his other requirements, the effects it produces, its extinction and conventions established by law as possible to add to it.

Key Words: Possessory pledge, Pledge without displacement contract, Solemnity of the contract of pledge without displacement, Conventions garment accessories to the contract of pledge without displacement.

* Este trabajo hace parte del proyecto patrocinado por FONDECYT bajo el número 1095068

** Doctor en Derecho por la Universidad de Navarra, España; profesor titular de Derecho Romano de la Facultad de Derecho de la Pontificia Universidad Católica de Valparaíso. Correo electrónico: a.guzman@vtr.net. Artículo recibido el 26 de octubre de 2009 y aceptado para su publicación el 24 de noviembre de 2009. 


\section{INTRODUCCIÓN}

Las normas contenidas en el artículo 14 de la ley $\mathrm{N}^{\mathrm{o}} 20.190$, publicada en el Diario Oficial de 5 de junio de 2007, que atañen a la prenda sin desplazamiento, distinguen un contrato de tal prenda y un derecho real de la misma, en razón de causa mediata a efecto. Decimos "causa mediata", porque el derecho real no es consecuencia directa del contrato, y para formarse aquél debe intervenir la inscripción de éste en el Registro de Prenda sin Desplazamiento, como lo dispone el primer segmento del artículo 25: "El derecho real de prenda se adquirirá, probará y conservará por la inscripción del contrato de prenda en el Registro de Prendas sin Desplazamiento [...]". La causa inmediata del derecho real es, por ende, la inscripción.

El presente trabajo se limitará estrictamente al que la ley llama contrato. Con todo, varios de los temas que a menudo se hacen ingresar en el esquema expositivo de todo contrato no han de ser presentados aquí más que sumariamente, por las razones que se ofrecerán en su momento.

Necesario es advertir que cuando en lo sucesivo vaya citado algún artículo de los que pertenecen al 14 de la Ley $\mathrm{N}^{\circ} 20.190$, por lo general se omitirá la indicación de esa pertenencia, de modo que deberá entenderse 162 una remisión tácita a este último.

\section{NoRmaS QUE RIGEN EL LLAMADO CONTRATO DE PRENDA SIN DESPLAZAMIENTO}

El que la ley denomina contrato de prenda sin desplazamiento se rige principalmente por las reglas contenidas en el artículo 14 de la ley $\mathrm{N}^{\mathrm{o}} 20.190$, como es natural. Pero, según el segmento segundo de su artículo 1, le son aplicables en subsidio las que el Código Civil establece para el contrato de prenda ${ }^{1}$. Como es sabido, esas normas se encuentran concentradas en el título $37^{\circ}$ del libro IV de dicho Código; pero el artículo 1 de la ley dice: "disposiciones del contrato de prenda del Código Civil", sin circunscribirlas a las que forman el título $37^{\circ}$; por consiguiente, también deben aplicarse subsidiariamente al contrato de prenda sin desplazamiento cualquier otra norma del Código Civil sobre el contrato de prenda, aunque no esté sita en su título $37^{\circ}$.

${ }^{1}$ Ley No 20.190, artículo 1: "En lo no previsto por la presente ley, se aplicarán las disposiciones del contrato de prenda del Código Civil”. 


\section{DEFINICIÓN}

El segmento primero del artículo 1 define que:

"El contrato de prenda sin desplazamiento tiene por objeto constituir una garantía sobre una o varias cosas corporales o incorporales muebles, para caucionar obligaciones propias o de terceros, conservando el constituyente la tenencia y uso del bien constituido en prenda. [...]".

La definición se comprende, a pesar de lo cual elegimos proponer otra. Diremos, pues, que él consiste en

"la convención entre el propietario de una o más cosas corporales o incorporales muebles, llamado pignorante, y un acreedor, llamado pignoratario, por la cual ambos consienten en afectarla y destinarla, sin traspaso de su tenencia, a garantía del pago preferente de créditos del pignoratario contra el pignorante o un tercero".

Cada uno de los elementos de esta definición quedará elucidado en lo que sigue.

\section{El ACTO REGULADO EN LA LEy No 20.190 NO ES UN CONTRATO SINO MERAMENTE UNA CONVENCIÓN}

1. La doctrina chilena, como es sabido, distingue la convención del contrato $^{2}$. Esta distinción, sin embargo, no emana del artículo 1438 del $C C$., la cual, por el contrario, parece abolirla. Dice: "Contrato o convención es un acto por el cual una parte se obliga para con otra a dar, hacer o no hacer alguna cosa [...]". De acuerdo con esta norma, contrato y convención serían sinónimos. De tal sinonimia resultaría que los acuerdos de voluntad merced a los cuales sus partes no se obligan en modo alguno a dar, hacer o no hacer una cosa no podrían ser llamados contratos o convenciones; tal fuere el caso, por ejemplo, de los acuerdos que extinguen obligaciones, o que modifican un contrato que antes las creó, o que se dirigen a la constitución

\footnotetext{
${ }^{2}$ Sobre esta materia, con detalle: Hernán Corral Talciani, "La definición de contrato en el Código Civil chileno y su recepción doctrinal. Comparación con el sistema francés", en Hernán Corral Talciani - Guillermo Acuña Sboccia (editores), Derecho de los contratos. Estudios sobre temas de actualidad, Santiago, Universidad de los Andes, Cuadernos de Extensión jurídica, N$^{\mathrm{o}}$ 6, 2002, pp. 69-97.
} 
o a la extinción de derechos reales o, en fin, a generar cualquier otro efecto que no sea el de crear obligaciones, como el pacto de los cónyuges para separarse de bienes y tantos otros. ¿Cómo denominar tales acuerdos? La tradición, que remonta al Derecho Romano y, más cercanamente, a Robert Pothier ${ }^{3}$, lo mismo que el uso común del hablar les imponen el nombre de convención también. El mismo Código no es ajeno a este uso, como se ve en sus artículos 152 (convención de separación de bienes), 801 (convenciones entre nudo propietario y usufructuario relativas a las mejoras), 1486 inciso $3^{\circ}$ (convención de destinación de una cosa), 1567 inciso $1^{\circ}$ (convención de resciliación), 1609 y 1611 (convención de subrogación); así que, para ese cuerpo legal, ciertamente hay convenciones que no son contratos. Por consiguiente, en el Código, la palabra 'convención' tiene dos significado: uno estricto, que designa el acto de dos en orden a crear derecho personales $\mathrm{u}$ obligaciones, el cual también se llama contrato; y otro amplio, que significa el acto de dos en orden a modificar o extinguir derechos personales o a crear, modificar o extinguir derechos reales y ciertos estados o situaciones, que permanece en el nombre general de convención. Así que una de dos: o en el artículo 1438 del $C C$. esa palabra está directamente tomada en su sentido estricto; o, bien, la definición contenida en esa disposición porta una especie de endíadis no sinonímica, o significación de un concepto a través de dos 164 palabras coordinadas, una de las cuales, en el contexto, es parte de la otra, igual que existe cuando el poeta dice: "pateris libamus et aurus" ("bebamos en copas y oro"), queriendo decir: "bebamos en copas de oro" o "en copas áureas", porque no toda copa es de oro ni todo oro forma copa ${ }^{5}$. En este caso, la endíadis "contrato o convención” viene a significar algo así como "contrato convencional", no porque haya contratos no convencionales, sino porque el contrato es una convención; o, bien, "convención contractual", porque sí hay convenciones que no son contratos ${ }^{6}$. Así entendidas las cosas, no existe el error que la doctrina suele imputar al artículo $1438 \mathrm{del} C C$., en orden a confundir contrato y convención ${ }^{7}$.

${ }^{3}$ Robert-Joseph Pothier, Traité des obligations, Paris, Bugnet, editor, Cosse et Marchal - H. Plon, 1871, vol. x, $1^{\mathrm{a}}$ parte, cap. $1^{\mathrm{o}}$, sec. $1^{\mathrm{a}}$, art. 1 , No 3 , en CEures de Pothier, pp. 4-5: el contrato es una especie de convención.

${ }^{4}$ Vergilius, Georgica, vol. II, p. 192.

${ }^{5}$ Véase Angelo Marchese - Joaquín Forradellas, Diccionario de retórica, crítica y terminología literaria, $4^{\mathrm{a}}$ ed., Barcelona, Ariel, 1994, p. 122.

${ }^{6}$ Se observará, en efecto, que, al prescindir de esta interpretación, la definición del artículo 1438 del $C C$. se queda sin dar el género próximo de "contrato", o sea, el de “convención” y sólo ofrece el género más remoto, vale decir, el de "acto"; lo que en materia de definición no es lo más correcto.

${ }^{7}$ Ya por Robustiano Vera en su comentario al Código Civil (1896) y por E. Sánchez en sus explicaciones al título $1^{\circ}$ del libro IV del Código (1897), entre otros. Detalles en Corral Talciani (n. 2), p. 84 y n. 44. Cfr. con Luis Claro Solar, Explicaciones de Derecho civil chileno 
2. Para la ley, la convención por la cual se afecta un mueble en prenda sin desplazamiento es un contrato; tal es lo que dice al definirla en su artículo 1: "El contrato de prenda sin desplazamiento tiene por objeto", etc.; y lo reitera con insistencia a lo largo de su articulado y en varias de sus rúbricas. De acuerdo con ello y en coordinación con el artículo 1438 del $C C$., de este acto deberían emanar obligaciones para una o para ambas partes. Sin embargo, el examen del articulado de la ley no deja ver tales efectos.

La prenda civil y la mercantil ofrecen un claro carácter contractual sobre todo derivado de la obligación que asume el pignoratario de restituir la cosa empeñada al pignorante, una vez extinguida la obligación que ella caucionaba. En la prenda de que aquí tratamos tal obligación no existe, debido a que el pignorante conserva la tenencia de la cosa pignorada (artículos 1 y 18), que no pasa, pues, al pignoratario, de guisa que éste nada debe restituir. Cierto es que, de acuerdo con el artículo 27, el pignoratario tiene el deber de alzar el derecho real de prenda inscrito, una vez pagada íntegramente la obligación que éste caucionaba; y que tal deber podría ser visto como el subrogante de la obligación de restituir la cosa en la prenda civil. Pero ese deber no emana del contrato sino de la ley.

Verdad es también que el pignorante puede llegar a quedar sujeto a ciertas abstenciones, consistentes en no utilizar, reemplazar, transformar o enajenar los componentes de un grupo de bienes o universalidad de hecho constituido en prenda (artículo 11 inciso $1^{\circ}$ ); en no gravar o enajenar la cosa pignorada (artículo 17); en no trasladarla del lugar convenido para su mantención (artículo 19) o en no utilizar la cosa empeñada más que de una forma especificada (artículo 19). Ahora bien, el impulso a convertir la sujeción a tales abstenciones en obligaciones contractuales de no hacer debe ser reprimido por dos razones:

i) porque las sujeciones concernientes no derivan de la esencia de la convención prendaria, sino de especiales pactos accidentales añadidos a ella, que, en consecuencia, pueden ser prescindidos de modo de no generarse entonces las abstenciones debidas y

ii) porque la infracción de las sujeciones a que nos referimos no da lugar a la exigencia de una prestación in natura de su contenido ni a la indemnización de perjuicios, mas sólo a la aceleración de la deuda principal.

Por ende, ellas no pueden ser convertidas en obligaciones propiamente tales del pignorante y constituyen nada más que cargas suyas. El pignoratario, asimismo, debe abstenerse de impedir que el pignorante inspeccione en cualquier momento los objetos dados en prenda (artículo 20); pero eso -que,

y comparado, vol. x: De las obligaciones, $1, \mathrm{~N}^{\mathrm{os}} 626-628$, pp. 566-567, reimpresión facsimilar de la edición de 1936, Santiago, Editorial Jurídica de Chile, 1992. 
por lo demás, está descrito como un derecho de inspección conferido al pignoratario por la ley- mejor es manifestación de apoyo al derecho real y no una obligación propiamente contractual.

El pignorante ni siquiera contrae la obligación de inscribir el llamado contrato en el Registro de Prendas sin Desplazamiento. De acuerdo con el diseño de la ley (artículo 24), esa inscripción es un deber de oficio que comparten el notario ante quien se otorgó y el Servicio del Registro Civil e Identificación, en cuanto el primero debe enviar al segundo los instrumentos del caso, para que el último proceda a la inscripción; y sólo para cuando estos organismos incumplieren sus deberes la ley habilita al "interesado", se entiende que en la inscripción, para pedirla directamente al antes mencionado servicio (artículo 24 inciso $2^{\circ}$, segmento final). En cualquier caso de negativa de éste a inscribir, el perjudicado tiene acción judicial para obligar al servicio a la ejecución del acto (artículo 28 inciso $\left.4^{\mathrm{O}}\right)$. Ahora bien, el interesado en la inscripción y el perjudicado por la negativa a inscribir es el pignoratario, en cuanto la ausencia de tal formalidad le impide adquirir el derecho real de prenda; y no el pignorante, a quien no puede vérselo como interesado en que sus bienes empiecen a quedar gravados con aquel derecho a favor de su acreedor, o como perjudicado porque aquello no acaezca; así que en esta materia nada obligacional incumbe al pignorante, cuya pasividad, por otro lado, no está sancionada en modo alguno en la ley.

Demás está decir que los derechos que pueden construirse a favor del pignoratario, como los de perseguir el objeto de manos de terceros, incluso del dueño (artículos 891 y 2393 del CC.), vender el objeto pignorado (artículos 29 de la ley y 2397 del $C$ C.) y pagarse preferentemente con el precio de su venta (artículo 15 de la ley y 2474 del $C C$.), no derivan de la convención y son inherentes al derecho real.

La única figura que puede hacer excepción al estado de cosas examinado es la responsabilidad fundada en culpa grave que pesa sobre el pignorante por la conservación de las cosas pignoradas 8 , cuya tenencia, uso y goce conserva (artículo 18), y que puede conducirlo a tener que indemnizar al pignoratario en razón de pérdida o deterioro de aquéllas. Aunque la medida de tal responsabilidad sea legal, la responsabilidad misma del pignorante deriva de la convención, como consecuencia natural de permanecer en su tenencia las cosas empeñadas; y no parece posible atribuirla a un efecto del derecho real. Pero ya se ve que en vez de una obligación propiamente tal se trata de cierta responsabilidad que afecta al pignorante. Con todo, si, sobre

${ }^{8} \mathrm{El}$ artículo 18 impone al pignorante responder de la conservación de la cosa empeñada como el depositario; y el artículo 2222 inciso $2^{\circ}$ del $C C$., a su vez, hace responsable a éste sólo por la culpa grave. 
la base de esto, aún se insistiere en atribuir contractualidad a esta prenda, igualmente hubiere de concluirse que resulta asaz débil tal carácter.

La precedente discusión nos conduce a un resultado aparentemente asombroso: el acto regido en el título $1^{\circ}$ de la ley no es un contrato; de donde que sea la calificación de "convención” la procedente a su respecto.

\section{CARACTERES DE LA CONVENCIÓN PRENDARIA}

Nos proponemos establecer algunos caracteres generales del acto definido por el artículo 1 de la ley. Establecido, como quedó, no ser fuente de obligaciones, carece de sentido indagar si es bilateral o unilateral, porque estos caracteres están montados sobre la base de existir obligaciones de una o de ambas partes en reciprocidad.

\section{Gratuidad de la convención de prenda sin desplazamiento}

Cosa distinta es con respecto a los caracteres de la onerosidad o gratuidad de nuestra convención, que no tienen relación con las obligaciones, sino con las utilidades y los gravámenes resultantes. Formulados tales caracteres en el Código Civil con referencia a los contratos, nada impide aplicarlos a las convenciones no contractuales. Ahora bien, para examinar el carácter gratuito u oneroso de la convención prendaria, necesario es distinguir las dos hipótesis posibles, de que sea el deudor de la obligación caucionada el que pignora por su propia deuda o de que un tercero sea quien constituya prenda por una deuda ajena (artículo 1: "para caucionar obligaciones propias o ajenas").

a) En el primer caso, la convención de prenda sin desplazamiento es gratuita en los términos del primer segmento del artículo 1440 del $C C$.: "El contrato es gratuito o de beneficencia cuando sólo tiene por objeto la utilidad de una de las partes, sufriendo la otra el gravamen [...]". La convención de que tratamos impone un gravamen al pignorante, consistente en dejar afectado algo suyo a una carga real de garantía prendaria, sin atraerle ninguna utilidad contractual ${ }^{9}$; y tiene por objetivo exclusivo la utilidad del

${ }^{9}$ Aunque a veces le atraiga alguna utilidad extrínseca, como la de conseguir recursos crediticios, por la obligación para cuyo pago constituye la prenda, que es, empero, extracontractual; sin hacer caudal que en muchísimas otras ocasiones ni siquiera una utilidad así consigue, como cuando la prenda se otorga por obligaciones no crediticias o si se la constituye en cumplimiento de algún deber de caucionar cierta responsabilidad, por ejemplo, cuando el tutor confiere prenda (véase el artículo 376 del $C C$.) en vez de la fianza tutelar dispuestas por los artículos 374 y 375 del $C C$. En contra Manuel Somarriva Undurraga, Tratado de las cauciones, $2^{\mathrm{a}}$ ed., Santiago, Contable Chilena, 1981, No 217, pp. 208-209; 
pignoratario en cuanto, por medio de ella, ha de gozar de dicha garantía y del privilegio de pago que lleva consigo. No se configura, pues, el esquema del contrato oneroso aplicado a la convención, descrito por el segundo segmento del mismo artículo: "El contrato es [...] oneroso, cuando tiene por objeto la utilidad de ambos contratantes, gravándose cada uno a beneficio del otro". A la utilidad que reporta el pignoratario no corresponde ningún gravamen suyo a favor del pignorante; $y$, como ya vimos, éste, aunque se grava, no recibe utilidad contractual alguna en la convención.

Esto mismo se puede decir de otra manera: la convención de que tratamos no contiene la exigencia de un precio que deba pagar el pignoratario al pignorante por el otorgamiento de prenda a que procede; así que tal prenda es gratis o gratuita para él.

b) En la hipótesis de una convención de prenda para caucionar deudas ajenas, entre el pignorante no deudor y el pignoratario, acreedor de un tercero, se repite el mismo esquema precedentemente descrito; de modo que la convención de prenda por deudas ajenas acordada entre ellos es igualmente gratuita.

Mas puede acaecer que un deudor haga cierta prestación (como una remuneración en dinero) o se obligue a hacerla a alguien para que él contraiga prenda a favor de su acreedor (cfr. con el artículo 2388 del $C C$.). En tal caso tiene lugar una convención innominada o derechamente un contrato del mismo género ${ }^{10}$ entre ambos, que es completamente distinto $\mathrm{y}$, por lo general, anterior al de prenda, en el cual el pignoratario no participa en modo alguno; de guisa que la operación no puede conferir carácter oneroso a la convención prendaria misma ${ }^{11}$.

Lo propio acaece cuando no es un deudor sino un tercero quien hace o se obliga a hacer una prestación a alguien para que constituya prenda a un acreedor de cierto deudor. En tal caso, la convención o el contrato innominados ${ }^{12}$ entre el tercero y el que va a constituir la prenda están aún más desligados de la convención prendaria final que tendrá lugar entre el que aceptó constituir la prenda por deuda ajena y el acreedor, quien, asimismo, permanece totalmente ajeno a la operación antecedente, la cual, pues, no da carácter oneroso a la convención prendaria.

Jorge López Santa María, Los contratos. Parte general, $4^{\mathrm{a}}$ ed., Santiago, Editorial Jurídica de Chile, 2005, tomo I, p. 117 n. 123, quienes ven en la eventual utilidad extracontractual del pignorante algo que permite calificar de onerosa a la prenda.

${ }^{10}$ Que incluso puede ser un mandato remunerado, en que el negocio encargado al mandatario es precisamente constituir la prenda: véase, más adelante, el cap. VIII, 3.

${ }^{11}$ Véase, al respecto Alejandro GuZmán BRITO, De las donaciones entre vivos. Conceptos y tipos, Santiago, Lexis Nexis, 2005, p. 47. En contra: López Santa María (n. 9), p. 117.

12 También es aplicable a esta operación lo dicho en la n. 10. 
Sin embargo, como se ha hecho notar ${ }^{13}$, la calificación que se dé a todo contrato prendario deja de tener interés práctico debido a que la determinación de las consecuencias que se seguirían de considerarlo gratuito u oneroso no fueron entregadas al intérprete por el Código, quien se encargó de fijarlas él mismo. Tales consecuencias atañen al grado de responsabilidad que rige en ese contrato y a la procedencia de la acción Pauliana para rescindirlo.

En efecto, el artículo 18 de la ley impone la responsabilidad del depositario al pignoratario, por la conservación de la cosa pignorada que permanece en su poder; y tal responsabilidad, según el artículo 2222 inciso $2^{\circ}$ del $C C$. se limita a la grave o lata; lo cual se corresponde bien con la idea del artículo 1547 del $C C$., según el cual es tal tipo de culpa por la que un deudor responde en los contratos que por su naturaleza son sólo útiles al acreedor, como es el caso del depósito. En el de la convención prendaria no hay acreedor, según vimos, pero sí una parte, el pignoratario, sólo al cual aquélla es útil; de modo que, al atender al criterio de la utilidad (que es el empleado por el artículo 1547 del $C C$.) resulta correcto que el pignorante responda únicamente de la culpa grave o lata por las cosas cuya tenencia conserva.

Por otro lado, el artículo $2468 \mathrm{del} C C$. hace sin más procedente la acción Pauliana a favor de los acreedor contra la constitución de prendas por el deudor ${ }^{14}$; y esta norma es del todo aplicable a la prenda sin desplazamiento; así que dicha acción procede sin que sea necesario determinar previamente si es gratuita u onerosa la convención prendaria.

\section{Accesoriedad de la convención de prenda sin desplazamiento}

a) El principio general de accesoriedad de las cauciones está recogido en el artículo 46 del $C C$.: "Caución significa generalmente cualquiera obligación que se contrae para la seguridad de otra obligación propia o ajena. Son especies de caución la fianza, la hipoteca y la prenda". Asimismo, en el artículo 1442 del $C C .:$ "El contrato es principal cuando subsiste por sí mismo sin necesidad de otra convención, y accesorio, cuando tiene por objeto asegurar el cumplimiento de una obligación principal, de manera que no pueda subsistir sin ella"; en el entendido que también aquí es necesario

${ }^{13}$ Somarriva Undurraga (n. 9), No 217, p. 2.092.

${ }^{14}$ Aunque se observará que esta norma dice: "Los acreedores tendrán derecho para que se rescindan los contratos onerosos y las hipotecas, prendas y anticresis que el deudor haya otorgado en perjuicio de ellos [...]”. Ahora bien, que esta norma haya sentido una necesidad de mencionar la prenda (lo mismo que la hipoteca y la anticresis) separadamente de los contratos onerosos parece indicar que no la comprende como un caso de estos últimos, sino como uno de los gratuitos. 
sustituir "contrato" por "convención”. Dicho principio, entendido según los términos con que lo expresan estas normas, significa que las cauciones sólo pueden ser constituidas en función de una obligación a la que sirvan de garantía. Sin ésta no pueden aquéllas preexistir, existir ni subsistir ${ }^{15}$. De manera especial, tal principio aparece declarado para la prenda en el artículo 2385 del $C C$. "El contrato de prenda supone siempre una obligación principal a que accede".

b) Algunos han considerado que la accesoriedad quedaría derogada cuando se aceptara una prenda de obligaciones futuras ${ }^{16}$. Aunque tal se afirma para la prenda con desplazamiento, igual tendría que valer para aquélla sin desplazamiento, en la cual rige el artículo 2385 antes citado; mas como la ley $\mathrm{N}^{\mathrm{o}} 20.190$ permite que ésta pueda ser constituida para obligaciones futuras (artículo 4), se significaría para tal caso que esta prenda no sería accesoria. Por lo demás, los artículos 2339, expresamente ${ }^{17}$, y 2413 del $C C$. de forma indirecta ${ }^{18}$, autorizan una fianza y una hipoteca de obligaciones futuras; $y$, de manera más amplia, la generalidad de los términos del inciso $1^{\mathrm{O}}$ del artículo $1461 \mathrm{del} C C$. : "No sólo las cosas que existen pueden ser objetos de una declaración de voluntad, sino las que se espera que existan [...]", que cubre a los dos objetos separados y necesarios sobre que recaen todas las cauciones, vale decir, la cosa con que se cauciona y la obligación

${ }^{15}$ Algunos autores y ciertas sentencias han interpretado que "subsistir" significa "seguir en existencia" no "empezar a existir", con apoyo en el Diccionario de la Real Academia. Véase: José Joaquín UGarte Godoy, "La nulidad de la cláusula de garantía general hipotecaria", en Revista de Derecho y Jurisprudencia N N $^{\circ} 8$, Santiago, 1991, Fasc. $3^{\circ}$, pp. 84-85, N ${ }^{\mathrm{os}} 14-16$. Debe observarse, empero, que el citado Diccionario trae dos acepciones, una, la ya indicada, cuando se aplica a las cosas; y otra, filosófica, que se aplica a las sustancias en general, que es la "existir". Ahora bien, reducir el significado del verbo 'subsistir', empleado en el artículo 1442, a sólo "seguir en existencia", implica mucho más que cuanto seguramente tuvieron en mente los autores de semejante exégesis, a saber: que ninguna garantía necesita de un acto principal para empezar a existir, aunque lo necesita para seguir en existencia, lo cual llanamente constituye una impropiedad, que da pie a crear cauciones sin apoyo en ninguna obligación por garantir, más allá del argumento que de aquello quiere conseguirse en sustento de la validez de la cláusula de garantía general (universal).

${ }^{16}$ Así Somarriva Undurraga (n. 9), No 230, pp. 216-218. Lo dice cuando objeta la posibilidad de poderse caucionar obligaciones futuras con prenda civil, pues, según él, si se pudiera, no quedaría respetado el artículo 2385 del $C C$., que exige una obligación a la que acceda dicha prenda.

${ }^{17} C C$., artículo 2339: "Puede afianzarse no sólo una obligación pura y simple, sino condicional y a plazo. Podrá también afianzarse una obligación futura; y en este caso podrá el fiador retractarse mientras la obligación principal no exista; quedando con todo responsable al acreedor y a terceros de buena fe, como el mandante en el caso del artículo 2173".

${ }^{18} C C$., artículo 2413 inciso $1^{\circ}$ : "La hipoteca podrá otorgarse bajo cualquiera condición, y desde o hasta cierto día". La hipoteca de una obligación futura queda sometida a la condición de que llegue a existir; y tal condición es una "cualquiera condición" permitida por esta norma. 
que se cauciona, también permite garantías cuyo objeto caucionado sea una obligación futura; así que, a final de cuentas y pese a la generalidad de los artículos 46, 1442 y 1461 del $C C$., la accesoriedad no valdría más que para la prenda sin desplazamiento; con el agravante de que, en el Código, habría una contradicción muy grave entre los dos primeros artículos que acabamos de citar y la autorización de caucionar obligaciones futuras con fianza e hipoteca en sus artículos 2339 y 2413.

c) Pero la accesoriedad se puede entender en otro sentido. El Código la refiere a una obligación en sus artículos 46, 1442 y 2385, como puede leerse en cada caso; pero si con tal referencia se entiende que la accesoriedad impide caucionar obligaciones futuras, la única manera de evitar una colisión entre esas disposiciones y los artículos 2339 y 2413 , que autorizan la fianza y la hipoteca de obligaciones futuras, pese a haber sido declaradas accesorias, es entender que este último carácter no va referido a una obligación principal, sino a un acto principal, por su naturaleza productor de obligaciones. Bajo esta idea las cauciones son accesorias porque necesitan de otro acto capaz de tener efecto obligacional para subsistir, en seguridad de cuyos efectos esenciales se constituyen. Ahora bien, un acto del que emana cierta obligación futura es suficiente, bajo ese respecto, para fundar como principal un acto accesorio caucionante también a futuro. Lo que se exige, pues, no es tanto que haya actualmente una obligación, sino que haya un acto productor de una obligación, aunque sea a futuro, del que el acto caucionante sea accesorio.

Se tendrá presente que en algunos casos el Código emplea el término ‘obligación' para referirse a un acto. Así, en su artículo 2335: "La fianza es una obligación accesoria, en virtud de la cual [...]", en circunstancias que la fianza no es una obligación sino un contrato; vale decir, no un efecto, sino una causa; o en su artículo 1647: "Si la nueva obligación se limita a imponer una pena para el caso de no cumplirse la primera [...]”, pues no es la nueva obligación sino un nuevo acto el que impone la pena; o en su artículo 1698: "Incumbe probar las obligaciones o su extinción al que alega aquéllas o ésta", porque el objeto de prueba no es la obligación sino el acto que la crea; o en su artículo 1708: "No se admitirá prueba de testigos respecto de una obligación que haya debido consignarse por escrito", cuando lo que debe consignarse por escrito es un acto del que emane cierta obligación. Así, también, en los artículos 46, 1442 y 2385 del $C C$., el término 'obligación' ahí empleado está pensado para el acto o, más en general, para la "fuente de una obligación".

Por otro lado, a veces el mismo Código predica la accesoriedad de las cauciones con respecto a algún acto y no a cierta obligación. Así, en los artículos 2344: "por la inejecución del contrato a que acceda la fianza"; 2413 inciso $2^{\circ}$ : "Podrá asimismo otorgarse [La hipoteca] en cualquier tiempo, 
antes o después de los contratos a que acceda [...]"; 2432: "La inscripción de la hipoteca deberá contener: $2^{\circ}$ La fecha y la naturaleza del contrato a que acceda la hipoteca [...]”.

El Código suele emplear la palabra 'obligación' abreviativamente por 'acto' o 'contrato' y en ocasiones considera que las cauciones son accesorias por acceder no a una obligación sino a un acto. Nada tiene de extraño, ya que la palabra 'obligación' que comparece en los artículos 46, 1442 y 2385 pueda ser entendida como abreviación de "acto obligacional"; y que la accesoriedad de las cauciones también pueda ser interpretada como accesión a tales actos.

d) Nuestra conclusión final es que la convención de prenda sin desplazamiento es accesoria, porque necesita de un acto principal del que emane una obligación presente o pueda emanar una futura, sin que, en este último caso, quede en lo más mínimo afectada su accesoriedad.

Este carácter también parece verse comprometido por la posibilidad de concebir la prenda en garantía general; pero a este tema nos referiremos por separado ${ }^{19}$.

\section{La convención prendaria es un título adquisitivo del derecho real de prenda}

172

La convención de prenda sin desplazamiento por sí misma no crea obligaciones; su función principal es servir de título para la adquisición del derecho real de prenda sin desplazamiento. Dice al respecto el artículo 25: "El derecho real de prenda se adquirirá, probará y conservará por la inscripción del contrato de prenda en el Registro de Prendas sin Desplazamiento".

Si se quiere insertar esta disposición en el sistema del Código Civil, es necesario decir que la inscripción actúa como tradición del derecho real de prenda sin desplazamiento (arg. ex artículo 670 inciso $2^{\circ}$ del $C C$.), por más que la posterior ley $\mathrm{N}^{0} 20.190$ no lo diga. Como por otro lado, toda tradición exige un título (arg. ex artículo 675 inciso $1^{\circ}$ del $C C$.), que es el que se inscribe en algún registro (artículo 686 inciso $2^{\circ}$ del $C C$., con respecto a los derechos reales inmuebles); he ahí, pues, la antes dicha proposición de que la convención prendaria resulta ser el título necesario para la tradición del derecho real de prenda sin desplazamiento, que se efectúa mediante una inscripción del mismo. Tal inscripción, cumple la función de modo de adquirir el derecho real.

${ }^{19}$ Véase, más adelante, el cap. VII, 4. 


\section{La constitución de prenda sin desplazamiento no envuelve donación}

La primera parte del artículo 1397 CC. dispone: "No hace donación a un tercero el que a favor de éste [...] constituye una prenda [...]". El tenor literal de la norma atañe a la relación entre un deudor y cierto tercero que constituyó prenda para caucionar la deuda de aquél frente a su acreedor. Por si pudiera pensarse que constituir prenda en garantía de una obligación ajena es hacer donación a su deudor, el Código advierte que no lo es. La misma advertencia hay que hacer para la relación del tercero que pignora lo suyo por deudas ajenas y el acreedor pignoratario, a quien, pues, no le dona; $y$, en fin, para la relación entre el deudor que pignora ante su propio acreedor, al cual tampoco dona. De lo que se deduce que la constitución de prenda no es donación con respecto a nadie. Lo cual también vale para la prenda sin desplazamiento.

Acerca de por qué la prenda no constituye donación nos hemos detenido en otro lugar y a él remitimos al lector ${ }^{20}$.

Pero es necesario advertir que la norma atañe a que no hay donación por el sólo hecho de constituirse una prenda a favor de un tercero; no dice que nunca pueda haber donación en ese caso; la cual se produce si el pignorante renuncia inicialmente y en forma gratuita a la acción de reembolso contra el deudor por quien salió como garante y acontezca que después pague la deuda garantizada al acreedor (para liberar la prenda) o sufra la realización de la cosa que había pignorado. En circunstancias normales, ambas hipótesis dan acción de reembolso al pignorante contra el deudor por cuya mora aquél se vio inducido a pagar o sufrió la realización prendaria. Pero si había renunciado a esta acción, a título gratuito y anticipadamente, entonces se configura una donación suya a favor del deudor, aunque sometida a la condición precisamente de llegar a pagar la deuda o de sufrir la realización. La razón de haber donación en tal hipótesis es que se produce un evidente empobrecimiento en el pignorante y un enriquecimiento en el deudor, en cuanto ve extinguida su deuda sin desembolso propio ${ }^{21}$.

Ahora bien, nada de esto significa que la constitución de prenda misma sea una donación. En el caso dicho, ésta se hace al deudor, que no interviene en la convención prendaria, no al acreedor que sí interviene en ella como pignoratario. Lo que sí significa es que esa prenda fue constituida por causa de donación, aunque sólo entre el pignorante y el deudor, lo cual es distinto.

${ }^{20}$ Véase GuZmán Brito (n. 11), pp. 82-84.

${ }^{21}$ Ibid. 


\section{El siguiente carácter de la convención prendaria es la solemnidad de su consentimiento}

A él pasamos a referirnos.

\section{CARÁCTER SOLEMNE DEL CONSENTIMIENTO PRENDARIO: LAS SOLEMNIDADES EXTERNAS}

1. El consentimiento o declaración de voluntad común de las partes, que el artículo 1 llama "objeto", y define redundantemente como "constituir una garantía [...] para caucionar obligaciones" debe ser en orden a afectar y destinar una cosa mueble a garantía del pago preferente de créditos del pignoratario contra el pignorante o un tercero. Este consentimiento se puede manifestar con los verbos típicos, aunque no, por cierto, prescritos, de "pignorar", "empeñar", "prendar", "dar en prenda" o "constituir, otorgar o conferir prenda", pues todos ellos significan precisamente afectar y destinar una cosa mueble a garantía preferente de pago de obligaciones; $y$ pertenecen a los más genéricos de "caucionar" 22 y "garantizar". También se podría recordar el verbo 'asegurar' que es el preferido en el Derecho 174 francés ('assurer', de donde 'sûreté'), pero que en Chile debe ser evitado -de hecho no se lo emplea ${ }^{23}$ - debido a su conexión específica con el contrato de seguro, que entonces conduciría a equívocos.

Ahora bien, la manifestación del consentimiento en orden a pignorar sin desplazamiento un mueble es solemne. Así lo dispone directamente el segmento primero del artículo $2^{24}$. Pero las solemnidades prescritas por la ley para el consentimiento se dejan agrupar en dos tipos, que denominaremos de solemnidades externas e internas. Las primeras consisten en ciertas actuaciones que deben rodear al consentimiento. Las segundas en la necesidad de expresar consentimientos en determinado sentido.

2. Por lo que atañe a las solemnidades externas, en realidad se trata de dos en alternativa, cuyos extremos están señalados por el segundo segmento del artículo 2:

“[...] El contrato, su modificación y su alzamiento, deberán otorgarse por escritura pública o por instrumento privado, en cuyo caso, las

${ }^{22}$ Cfr. con el artículo 46 del $C C$.

${ }^{23}$ Aunque a veces aparece en el Código, como en sus artículos 2384: “[...] para la seguridad de su crédito"; y 2392 inciso 20: "No se podrá retener una cosa del deudor en seguridad de la deuda [...]".

${ }^{24}$ Ley $\mathrm{N}^{\mathrm{o}}$ 20.190, artículo 2, primer segmento: "El contrato de prenda sin desplazamiento es solemne. [...]". 
firmas de las partes concurrentes deberán ser autorizadas por un notario y el instrumento deberá ser protocolizado en el registro del mismo notario que autoriza [...]".

Como es natural, estas solemnidades son necesarias para el perfeccionamiento inicial de la convención, mas también para sus sucesivas modificaciones. También para su resciliación o mutuo disentimiento, que el artículo 2 incluye bajo la voz 'alzamiento'25.

3. Procede ahora examinar el detalle de éstas que hemos denominado solemnidades externas.

a) El primer extremo de la alternativa de solemnidades es la escritura pública; y nada más hay que decir al respecto, digno de ser observado adicionalmente, que no sea la ausencia de prescripción legal sobre competencia de algún notario ante el cual se otorgue la escritura, que puede ser libremente escogido por las partes.

b) El segundo extremo es el instrumento privado con ciertas circunstancias, que son

i) las firmas de las partes concurrentes a la convención y a su instrumento;

ii) la autorización de tales firmas por un notario;

iii) la protocolización del instrumento autorizadamente firmado;

iv) en el registro del mismo notario que autorizó las firmas de las partes.

Se observará que la ley tampoco da norma sobre competencia notarial para la suscripción del instrumento y la autorización de sus firmas -igual que en el caso ya preanunciado de la escritura pública-. Por consiguiente, las partes de la convención pueden acudir a cualquier notario para aquellos fines, con independencia del domicilio de cada una, o del lugar en que actualmente se encuentren las cosas que son objeto de la pignoración o en que se contrajo la deuda por caucionar. Pero también se observará que, una vez escogido el notario para la firma y la autorización, queda legalmente fijada en él mismo la competencia para la protocolización del documento ya firmado y autorizado ("ser protocolizado en el registro del mismo notario que autoriza").

Tampoco establece la ley que la protocolización deba tener lugar con sujeción a cierto plazo; esto es, firmado que sea el instrumento de la convención y autorizadas sus firmas por cierto notario, no hay prescrito tiempo alguno para que tenga lugar la protocolización de aquel instrumento, así que resulta permitido instar por la protocolización o proceder a ella en

${ }^{25}$ Porque la ley también piensa en el acto destinado a alzar el derecho real, procedente una vez pagada la totalidad de la deuda (artículo 27). 
cualquier momento posterior a la autorización de las firmas. Tal conclusión no sólo deriva del silencio legal sino, también, de cuanto establece el artículo 24:

"Dentro del plazo de tres días hábiles [...], contado [...], tratándose de instrumentos privados, desde su fecha de protocolización, el notario deberá enviar para su inscripción en el Registro de Prendas sin Desplazamiento, una copia autorizada del contrato de prenda [...]”.

La ley dispone un plazo al notario, dentro del cual debe remitir una copia autorizada del instrumento privado en que conste la convención de prenda sin desplazamiento, al Registro de Prendas sin Desplazamiento -que administra el Servicio de Registro Civil e Identificación (artículo 28)-. Pero ese plazo se cuenta desde la fecha de la protocolización; no desde aquélla de la firma del instrumento por las partes o de la autorización de sus firmas. Como es así, queda expedito distanciar la autorización de la protocolización cuanto se quiera en el tiempo, sin otra consecuencia que no sea la intrínseca de postergarse la perfección de la convención y su validez hasta que se proceda a la protocolización. Dicho de otro modo, la ley no ha prescrito la unitas actus para la ejecución de las distintas solemnidades 176 ordenadas para la celebración y perfección de la convención de prenda sin desplazamiento mediante instrumento privado.

4. La elección de uno de las dos solemnidades en alternativa que para la perfección de la convención ofrece el artículo 2 tiene, entre otras, la importancia de dejar establecida una diferente fecha de oponibilidad frente a terceros, según la alternativa escogida.

Para la hipótesis de que la convención adopte la solemnidad de la escritura pública, la ley nada dice acerca de su fecha; y entonces cabe aplicar la regla general sobre la materia, contenida en el artículo 1700 del $C C$. Según ella, la fecha de la convención es la de la escritura pública misma; y tal fecha es oponible entre las partes y frente a terceros.

Para cuando la convención prendaria adopte la solemnidad del instrumento privado, el artículo 2 de la ley, inmediatamente de terminada la descripción de tal solemnidad, añade: "En este caso, respecto de terceros la fecha del contrato será la de su protocolización”. Así que, en esta hipótesis, la convención solemne ofrece dos fechas:

i) frente a terceros, y es la de su protocolización ${ }^{26} y$

ii) entre las partes, y ahora es la que se registre en el instrumento mismo,

${ }^{26}$ La cual, atendido lo dispuesto por el artículo 419 COT., es la de su anotación en el repertorio. 
si éste es mandado tener por reconocido en los términos del artículo 346 del $C P C .{ }^{27}$. Por fecha del instrumento, empero debe entenderse la que señale el notario que autorizó las firmas de las partes, en la fórmula de autorización ${ }^{28}$. Entretanto, el instrumento de la convención no sea mandado tener por reconocido, su fecha oponible entre las partes es, sin embargo, la de la protocolización.

5. Tanto la firma de cada parte como la autorización notarial de tales firmas, igual que la protocolización del instrumento practicada en el registro del mismo notario autorizante son solemnidades cumulativamente prescritas (“deberán” dice la ley) para la convención en consideración a ella y no a la calidad o estado de las personas intervinientes, así que su omisión o algún defecto en ellas produce la nulidad absoluta de todo la convención (artículo 1682 inciso $1^{\circ} \mathrm{del} C C$.).

Es conveniente hacer notar que, por el contrario, no incurre en nulidad la convención que sufrió un distanciamiento, por extenso que sea, entre el momento de la autorización de las firmas del instrumento que lo contiene y el de la protocolización de este último, porque, como vimos, no está prescrita la unitas actus al respecto. También vale insistir especialmente en que la protocolización del instrumento privado en el registro de un notario distinto a aquél que autorizó sus firmas sí es causa de nulidad absoluta de la convención.

\section{CARÁCTER SOLEMNE DEL CONSENTIMIENTO PRENDARIO: LAS SOLEMNIDADES INTERNAS O MENCIONES FORZOSAS}

\section{Generalidades}

En cuanto a las solemnidades internas, ellas consisten en ciertas manifestaciones de voluntad que la ley ordena expresar en el documento convencional, sea éste la escritura pública, sea el instrumento privado. Las llama "menciones".

${ }^{27}$ Debe insistirse que lo dicho por el artículo 2 atañe a la fecha de oponibilidad de la convención frente a terceros. Otra cosa es la fecha de oponibilidad del derecho real de prenda frente a los mismos que, según el artículo 25, es la de inscripción de esa misma convención en el Registro de Prendas sin Desplazamiento.

${ }^{28} \mathrm{El}$ artículo $425 \mathrm{del} \mathrm{COT}$. ordena a los notarios dejar constancia de la fecha en que se firma un instrumento privado, las firmas de cuyos intervinientes autorizan. De esta manera, cualquiera que sea la fecha que aparezca en el cuerpo del instrumento, debe reputarse que la de éste es aquélla que el notario hizo contar en la autorización. 


\begin{abstract}
$\mathrm{Al}$ respecto, dice el artículo 3:
"El contrato de prenda deberá contener, a lo menos, las siguientes menciones:/ 1) La individualización de sus otorgantes;/ 2) La indicación de las obligaciones caucionadas o bien de que se trata de una garantía general. En caso que sólo se refieran los documentos donde constan las obligaciones garantizadas y éstos no estuvieren incorporados en un registro público, deberán ser protocolizados en copia simple al momento de la celebración del contrato de prenda;/ 3) La individualización o la caracterización de las cosas empeñadas, y/ 4) La suma determinada o determinable a la que se limitare la prenda o la proporción en que debiere caucionar diversas obligaciones, si fuere el caso".
\end{abstract}

Se trata de menciones forzosas (“deberá”), pero mínimas (“a lo menos”). Lo cual significa que ni está exigido que sean las únicas ni prohibido que haya otras no prescritas. De hecho, a través del articulado de la ley se encuentran tipificadas ciertas menciones posibles, cuya omisión no necesariamente arrastra nulidad; a ellas nos referiremos por separado ${ }^{29}$; y las partes pueden incorporar cuantas menciones o pactos, convenios, acuerdos o cláusulas estimen convenientes para la lícita regulación de sus intereses.

\title{
2. Primera mención:
}

La individualización de los otorgantes de la convención

La primera mención exigida es la individualización de los otorgantes de la convención (artículo $3 \mathrm{~N}^{\mathrm{o}}$ 1), es decir, de sus partes: el pignorante, que solemos -y también las leyes- llamar deudor prendario, aunque esta última denominación no siempre es correcta; y el pignoratario o acreedor prendario. Teóricamente podrían intervenir en el documento convencional otras personas como, por ejemplo, el dueño de las cosas pignoradas que consiente en su pignoración por un tercero (artículos 2390 del $C C$. y 13 inciso $2^{\circ}$ de la ley). Pero ningún interviniente que no sea el pignorante o el pignoratario es otorgante de la convención, aunque sea otorgante de algún convenio o acto que se le anexe o añada; así que su individualización no es algo exigible para la integridad de convención, aun cuando sí lo sea para aquélla del convenio o acto del que ese tercero sea parte.

a) El artículo $3 \mathrm{~N}^{\mathrm{o}} 1$ pide la individualización de los otorgantes, pero no indica la manera de hacerla. Ahora bien, una persona puede ser individualizada de dos maneras:

${ }^{29}$ Véase, más adelante, el cap. XI. 
i) por su nombre, bajo el cual se entiende el llamado "nombre de pila" o "propio" y los apellidos del padre y de la madre; también el seudónimo y, asimismo, el "alias" o "sobrenombre" con que socialmente es identificada la persona o

ii) por una demonstratio o indicación de circunstancias individualizantes, como son el lugar del nacimiento, la nacionalidad, la edad, la morada y el domicilio, el lugar de la vecindad y, si los tiene la persona, la profesión u oficio, el estado civil, el cargo; y eventualmente otras circunstancias.

El artículo 1016 inciso $1^{\circ}$ del $C C$., por ejemplo, exige el señalamiento de todas las circunstancias dichas (menos el cargo), en función de individualizar al testador, empleando, por ende, la técnica contraria a la recurrida por el $\mathrm{N}^{\mathrm{o}} 3$ del artículo 1 de la ley. Aquella disposición, en efecto, no requiere que el testador sea individualizado en el testamento, pero ordena aponer ciertas indicaciones que cumplen la función de individualizarlo; en tanto el articulo $3 \mathrm{~N}^{\circ} 1$ únicamente exige la individualización de los contratantes, mas se abstiene de señalar, como quedó advertido, los extremos que deben ser indicados en función individualizante.

Por consiguiente, se cumple con la exigencia de la ley cuando en el documento prendario se mencionan, bien el nombre de sus otorgantes, bien unas demonstrationes individualizantes de los mismos, bien aquél y éstas, porque la ley no ha dicho que la individualización deba ser por el nombre; sólo ha exigido que deba haber individualización. Así que vale conferir prenda a "la persona que ahora vive en tal parte"; si "en tal parte" vivía una única persona en el momento de la convención. Se trata de una específica aplicación del principio contenido en el artículo 1560 del $C C$.: "Conocida claramente la intención de los contratantes, debe estarse a ella más que a lo literal de la palabras"; de guisa que, si no hay ambigüedad en la persona individualizada en el documento, a ella hay que estar.

Cosa distinta, como veremos, es que la mención empleada no permita conocer a ninguna persona o resulte aplicable a más de una. De esto se sigue que omitir la indicación de algún extremo de aquéllos que máximamente suelen usarse para individualizar no vulnera la ley, si es que se indicó otros que sí cumplen función individualizante. Lo aconsejable, por cierto, es señalar la mayor cantidad de circunstancias posible.

b) La individualización puede resultar ambigua. Supóngase que hay dos personas llamadas "Ticio", padre e hijo, y en el documento alguien aparece confiriendo prenda a Ticio. En tal caso, la individualización del pignoratario es ambigua, porque se puede aplicar a dos personas y no se sabe a cuál. Pero si de los dos Ticio, uno, por ejemplo el padre, era acreedor del pignorante, he ahí que existe la tentación de sostener que el pignoratario es, empero individualizable cuando se atiende a su dicha calidad de acreedor, 
bajo el concepto de que la intención de los contratantes del caso no pudo ser otra que la de celebrar prenda con un acreedor como pignoratario, atendido el carácter accesorio de la convención, etcétera. Pero hay falacia en semejante argumento, consistente en resolver una cuestión de hecho por una consideración de Derecho; porque bien pudo haber acaecido que en la realidad el documento haya sido efectivamente celebrado con Ticio no-acreedor. De que no haya debido serlo, pues, no se puede concluir que no lo fue. Otra cosa es si el documento confiriera la prenda "a Ticio acreedor”, porque en este caso la parte sí está individualizada por una circunstancia de hecho comprobable, de manera que se aplicará a Ticio que sea acreedor y no ciertamente a aquél que no lo sea.

De todos modos, existe una base imposible de superar: la ley exige que en la convención haya una individualización. Eso significa que, aunque no exista duda sobre quién es la persona individualizada en el documento, si la base individualizante no está mencionada en él, no se puede atender a la individualización que dimana de circunstancias no mencionadas, por más ciertas e individualizantes de hecho que aparezcan. De este modo, si se confiere prenda sin indicar en modo alguno a quién, por más que se prueba que el pignoratario pensado fue Cayo, se vulneró la ley, porque ninguna individualización hubo en el documento.

c) Cosa distinta es, como quedó anunciado, que haya error en la individualización usada. El error puede incidir en el nombre o en la demonstratio o en ambos. Supóngase que se confiere prenda a Ticio, que vive en tal parte; y en la parte indicada vive Cayo, mientras Ticio en tal otra. Si el nombre es verdadero, aunque sea falsa la demonstratio, se está al nombre; así que probado que el documento lo otorgó Ticio, aunque sea falso su domicilio mencionado, aquél vale con él; y, viceversa, probado que lo otorgó el que vive en tal parte, aunque sea falso el nombre con que se lo mencionó, el documento vale con él. Si ambos son falsos, se aplican las reglas generales, según las cuales acertado el hecho de quién lo otorgó se está a él más que a las palabras con que se lo indicó (cfr. el artículo 1569 del $C C$., antes transcrito); de modo que, en el ejemplo, acertada que la persona que otorgó el documento es Ticio o, bien, la persona que vive en tal parte, vale con él, aunque el domicilio, en el primer caso, o el nombre en el segundo, sean falsos.

En resumen, la individualización de las partes no debe faltar; en caso contrario, la ley queda transgredida; pero no lo es si la que hay resulta errónea o ambigua, con tal que el error sea superable de acuerdo con las reglas generales. 


\section{Segunda mención: \\ La indicación de las obligaciones caucionadas o la indicación de haber garantía general. La prenda sin desplazamiento en garantía especial.}

La segunda mención legalmente exigida es una de estas dos en alternativa:

i) la indicación de las obligaciones caucionadas o, bien,

ii) la de que la prenda convenida es una garantía general (artículo 3 $\mathrm{N}^{\mathrm{o}} 2$ ).

a) La ley permite, que la convención de prenda sin desplazamiento sea celebrada tanto como garantía especial cuanto como general. Se la celebra bajo la primera modalidad cuando la caución es establecida para obligaciones determinadas, individualizadas y especificadas, aunque sean muchas; y ya veremos cuándo se la celebra bajo la segunda modalidad. Si las partes han tenido la intención de convenir una prenda especial, entonces es necesario que indiquen, esto es, determinen, individualicen y especifiquen en el documento las obligaciones caucionadas con la prenda que convienen; cuando su intención, en cambio, fue establecer una prenda general, ahora es necesario decir expresamente que la prenda convenida es general.

Porque, en efecto, se observará que cuando la prenda acordada es especial, la ley no exige declarar en forma expresa que es especial; y resulta suficiente individualizar en la convención las obligaciones caucionadas; así que la calificación de especial que se dé a la prenda es consecuencia o deducción posterior a partir de la indicación o especificación de las obligaciones que se caucionan. Podemos decir que en tal caso hay una garantía especial tácita. Expresa fuere cuando se declara que es especial; pero la ley no exige una tal declaración.

Se pregunta ahora si rige lo mismo cuando la prenda es general; vale decir, si el carácter de general que se quiere dar a la prenda convenida debe ser concedido explícitamente; o si resulta suficiente delimitar un género de obligaciones caucionadas, sin determinación o especificación de ninguna, en modo tal que de este hecho se deduzca que es general. La respuesta se inclina por la primera posibilidad, en cuyo favor depone la letra de la ley: "La indicación [...] de que se trata de una garantía general". De acuerdo con esto, es necesario decir en forma precisa que la prenda convenida es en garantía general; así que vulneraría la ley una garantía general tácita, que se tiene cuando, sin decirse que ella es general, sólo se describe un género de obligaciones caucionadas, sin especificación concreta de ninguna; como cuando se declara, por ejemplo, que la prenda va constituida para caucionar todas las obligaciones que emanen de tal contrato de financiamiento. Cierta cláusula así pertenece a una garantía general, aunque las partes no hayan dicho que es general. 
Ahora bien, como decimos, la letra de la ley es clara en orden a exigir que el carácter de general dado a la prenda sea expreso; así que no es posible una prenda general tácita. Podría, empero sostenerse que la posibilidad de una garantía general tácita, aunque no esté en la letra legal, sí está en su sentido, porque no hay razón de fondo alguna que la impida. Pero en realidad la hay: la descripción de un género de obligaciones caucionadas sin el añadido expreso de ser garantía general la prenda que se conviene en su caución puede dejar en ambigüedad u oscuridad el verdadero carácter de la operación; y tales defectos desaparecen si va rotulada expresamente de general. Así que cuando la letra de la ley exige la declaración expresa de que tratamos, no lo hace sin razón ni por un capricho o descuido del legislador, sino en función de certidumbre acerca del carácter de la convención y de seguridad jurídica.

Nada impide combinar una prenda general y una especial. Las partes pueden determinar o especificar ciertas obligaciones, declarando o no que la prenda es especial para ellas, y, entonces, sin más es especial; y, además, describir un género de otras obligaciones respecto de las cuales al mismo tiempo declaran expresamente ser general la prenda, y así será. Obrando de esta manera, en efecto, han cumplido las exigencias legales y no hay contradicción, porque los campos han sido delimitados; la caución, por consiguiente, deberá sustanciarse en su momento según lo acordado.

b) Acerca de la manera de "indicar" las obligaciones caucionadas y dar lugar, por ende, a prenda en garantía especial, el artículo 24 de la ley añade la exigencia de ser "precisa" la indicación. En su parte pertinente, en efecto, dice:

"Dentro del plazo de tres días hábiles [...] el notario deberá enviar para su inscripción en el Registro de Prendas sin Desplazamiento, una copia autorizada del contrato de prenda [...] y una copia de los documentos en que consten las obligaciones garantizadas que se hubieren protocolizado en su registro, si éstas no estuvieren indicadas precisamente en el contrato de prenda”.

La disposición ordena al notario enviar al Registro de Prendas sin Desplazamiento una copia de los documentos en que consten las obligaciones garantizadas y que debió, por mandato del artículo $3 \mathrm{~N}^{\mathrm{o}} 2$, ser protocolizada en su registro, como veremos ${ }^{30}$. Ahora bien, ella misma describe la protocolización que supone bajo la condición de que las obligaciones garantizadas ("éstas") "no estuvieren indicadas precisamente en el contrato de prenda".

${ }^{30}$ Véase, más adelante, el cap. VII, 5. 
Así que podemos aceptar que en esta parte la ley complementa el artículo $3 \mathrm{~N}^{\mathrm{o}} 2$, que por sí mismo exige una "indicación de las obligaciones caucionadas", en el sentido de que esa "indicación", cuando se la haga, debe hacerse "precisamente".

En torno al punto de cómo se cumple en concreto con la exigencia de "indicación precisa" de las obligaciones caucionadas, dice el artículo 30 de la ley, en su parte aquí interesante:

"La escritura pública o la copia autorizada del instrumento privado en el que conste el contrato de prenda, protocolizado de conformidad con el artículo $2^{\circ}$ de esta ley, tendrá mérito ejecutivo sin necesidad de reconocimiento previo, respecto de las obligaciones que se contraigan en los mismos o que se individualicen con precisión, en cuanto a su origen, monto, plazo e interés. Si en el contrato de prenda no se indica la obligación caucionada, para proceder a la ejecución deberá acompañarse un título con mérito ejecutivo en el que conste dicha obligación. [...]”.

La oración que actúa como sujeto del conjunto ("La escritura - esta ley") describe los dos tipos de documento que pueden legalmente contener la convención prendaria; vale decir, la escritura pública o el instrumento privado, con las firmas de sus partes autorizadas por un notario y protocolizado en el registro del mismo notario, todo ello según el articulo 2, que antes estudiamos. Pero como el instrumento privado debió ser protocolizado, lo exigido exhibir en esta norma procesal no pudo ser el original de aquél, y debió contentarse, por fuerza de las cosas, con una "copia autorizada" del mismo, que es lo que de hecho dice.

En su parte dispositiva, la norma expresa que la escritura o la copia autorizada del instrumento privado protocolizado, continentes de la convención prendaria, tienen mérito ejecutivo propio, vale decir, sin necesidad de previo reconocimiento judicial de deuda o firma, respecto:

i) de las obligaciones que se hayan contraído en la escritura o en el instrumento privado (referidos ambos en la norma mediante la expresión "en los mismos") o

ii) de las obligaciones que se individualicen con precisión, en cuanto a su origen, monto, plazo e interés.

La verdadera alternativa que se ofrece en esta parte de la norma es entre obligaciones contraídas en el documento de la convención (escritura o instrumento privado) y obligaciones no contraídas ahí mismo. Dicho de otra manera, piensa en las dos posibilidades normales, de que

i) la convención principal y la prenda consten en el mismo documento o

ii) de que consten en documentos separados y aparte. 
No piensa, pues, como aparenta decir, entre obligaciones contraídas en el documento de la convención y obligaciones que se individualicen con precisión, en cuanto a su origen, monto, plazo e interés, como si las contraídas en el documento aparte no necesitaran una individualización del tipo señalado. No puede ser esta última la verdadera alternativa, porque una obligación contraída en el documento prendario que no estuviera individualizada de la manera dicha, en ningún caso podría dar lugar a que aquél tuviere mérito ejecutivo (del cual trata el artículo 30), por iliquidez, o incertidumbre o inexigibilidad. De esta forma, sea que el acto principal y el accesorio, vale decir la prenda, consten en el mismo documento, trátese de la escritura pública, trátese del instrumento privado con firmas autorizadas por un notario, sea que la convención prendaria conste en algunos de esos dos documentos y el acto principal al que aquélla accede en otro distinto, en ambos casos las obligaciones caucionadas deben aparecer individualizadas con precisión en cuanto a su origen, monto, plazo e interés, pero en el documento prendario mismo (la escritura o el instrumento privado).

Así que la "indicación de las obligaciones caucionadas" exigida por el artículo $3 \mathrm{~N}^{\mathrm{o}} 2$, debe ser hecha con precisión (artículo 24), en lo que coincide el artículo 30 (“que se individualicen con precisión”); y esta precisión consiste en el señalamiento del origen de la obligación, vale decir, 184 de su fuente, y de su monto, de su plazo y de su interés. De lo cual fluye la siguiente definición de la prenda con desplazamiento en garantía especial, como aquélla constituida para caucionar obligaciones precisamente señaladas en su origen o fuente, monto, plazo e interés en el documento prendario mismo, aunque se hayan contraído en otro.

Con todo, alguien podría sostener que los extremos de precisión exigidos por el artículo 30 exceden las del artículo $3 \mathrm{~N}^{\mathrm{o}}$ 2, que sólo ordena una "indicación" de las obligaciones caucionadas; y que la excedencia se debe a que el artículo 30 considera al documento de la convención sólo en cuanto título ejecutivo, sin haber pensado en referirse a algún requisito general; y que sólo entonces resulten congruentes esas exigencias de precisión, porque, como es sabido, la ejecución tiene que fundarse en una deuda cierta, líquida, actualmente exigible y no prescrita en su título ejecutivo; todo lo cual emana de aquellas precisiones. Lo cual significaría que podría bastar que el documento de la convención prendaria indicase las obligaciones, sin necesidad de que sea con precisión y señalamiento de su origen, monto, plazo e intereses. Pero se trata nada más que de una apariencia, porque, de hecho, no se sabría aceptar otra manera de indicar una obligación, como pide el artículo $3 \mathrm{~N}^{\mathrm{o}} 2$, que no consistiera en señalar, al menos, los extremos que pide el artículo 30. Por lo demás, debe tenerse presente que se trata de una prenda en función de garantía especial, así que mientras menos indicativos sean usados para referir una obligación, o mientras menos específicos sean ellos, más se aproxima la 
garantía a su función general. Esta distinción de funciones exige, por su propia naturaleza, una individualización, y la ley se contenta con los extremos del artículo 30, a saber: origen, o fuente, monto, plazo e interés.

\section{Segunda mención (continuación): la prenda sin desplazamiento en garantía general}

a) ¿Cuándo, en cambio, se celebra una prenda en garantía general ${ }^{31}$ ? La pregunta parece superflua, pero no lo es, porque la ley no define que sea una "garantía general" ni en materia prendaria ${ }^{32}$ ni en aquella hipoteca-

${ }^{31}$ Con respecto a la prenda civil en función de garantía general, la doctrina y la jurisprudencia están conformes en su invalidez. Véanse: Somarriva Undurraga (n. 9), $\mathrm{N}^{\mathrm{O}}$ 238, pp. 221-223; Jorge López SAnta María, "Informe sobre contrato de línea de crédito. Cláusula de garantía general prendaria. Distinción entre contratos civiles y contratos mercantiles", en Revista de Derecho de la Universidad Católica de Valparaíso No 4, Valparaíso, 1980, pp. 121-128, especialmente pp. 125-128. Sin discusión, ella es inadmisible en la prenda mercantil, porque el artículo $815 \mathrm{del} C$. de $C$. exige que ese contrato, que debe constar en escritura pública o en documento privado protocolizado, también debe contener la declaración de la "suma de la deuda", para que el acreedor goce de la preferencia prendaria, y aquello es incompatible con el carácter de la garantía general. La misma incompatibilidad acaece en la prenda de mercaderías depositadas en almacenes generales, porque el artículo 8 $\mathrm{N}^{\mathrm{o}} 2$ de la ley $\mathrm{N}^{\mathrm{o}} 18.690$, de 1988, exige que en el endoso del vale de prenda debe enumerar "el monto del capital e intereses del o de los créditos" garantizados.

${ }^{32}$ Las leyes que han estatuido sobre la posibilidad de conferir prenda en garantía general, en efecto, se limitan a usar esta expresión, sin definirla, como en el artículo 48 de la ley $\mathrm{N}^{\mathrm{o}}$ 5.687, de 1935: Sobre el contrato de prenda industrial (DO. de 17 de septiembre de 1835): "El deudor prendario tendrá derecho, antes del vencimiento del plazo, a pagar su deuda y exigir la cancelación de su inscripción de prenda; salvo el caso en que la referida prenda se hubiere constituido también como garantía general de otras obligaciones pendientes"; o en el artículo 3 de la ley $\mathrm{N}^{\circ}$ 18.112, de 1982, que: Dicta sobre prenda sin desplazamiento (DO. de 16 de abril de 1982): "El contrato de prenda sin desplazamiento debe contener, a lo menos, las siguientes menciones:/ b) La indicación de las obligaciones caucionadas o la expresión de que se trata de una garantía general”. Más aún, la primera norma citada incluso restringe el alcance de lo que comúnmente se entiende por "garantía general", porque la entiende sólo con respecto a otras obligaciones "pendientes", concepto éste que únicamente se puede aplicar a las sujetas a condición o plazo suspensivos, mas no a las que actualmente no existen y pudieran existir en el porvenir. Por otro lado, el artículo 5 de la ley $\mathrm{N}^{\mathrm{O}} 4.287$ de 1928: De prenda bancaria sobre valores mobiliarios a favor de los bancos (DO. de 23 de febrero de 1928), contiene una definición relativa a la extensión -muy dilatada- de la garantía que ofrecen los valores mobiliarios pignorados en conformidad con sus normas, cuando dice: "Las prendas que se constituyan en favor de un Banco en conformidad a las disposiciones de esta ley, servirán de garantía a todas las obligaciones directas o indirectas de cualquier clase que el dueño de la prenda tenga o pueda tener a favor del mismo Banco, a menos que conste expresamente que la prenda se ha constituido en garantía de obligaciones determinadas"; y el artículo 55 inciso $1^{\circ}$ del decreto con fuerza de ley $\mathrm{N}^{\circ} 126$, de 1953, que creó y organizó el Banco del Estado de Chile $(D O$. de 
ria $^{33}$ y los autores dan de ella una noción que no es la correcta, pues tienden a considerar como "general" la que en realidad es una garantía universal ${ }^{34}$. Una garantía es universal cuando cauciona la totalidad de las obligaciones que una persona tenga con respecto a cierto acreedor, y haya de tener para con él, o sólo las primeras, o sólo las segundas, o una cuota de unas u otras, y en cualquier caso sin especificación, determinación o individualización ni necesario conocimiento de ninguna. Como acaece en todos los actos universales, la descripción de la totalidad incluye automáticamente a los individuos del presente y del porvenir, aunque no se los conozca ${ }^{35}$. El opuesto

24 de julio de 1953) incluye una norma que también impone una extensa cobertura a la garantía que ofrece la prenda agraria otorgada a ese banco por el deudor o un tercero: "La prenda agraria que se constituya a favor del Banco garantizará todas las obligaciones directas o indirectas que el dueño de la cosa dada en prenda adeudare o llegare a adeudar a la Institución. Esta disposición se aplicará también al caso de garantía de prenda agraria constituida para caucionar obligaciones de un tercero". Pero se observará que en ninguno de ambos casos se dice tratarse de una garantía general lo ahí definido; así que no es posible adoptar el contenido de los artículos citados como base para construir una definición de lo que sea la garantía general. De hecho, como diremos, lo que en estas normas se define no es una garantía general sino universal.

${ }^{33}$ En ésta también hay casos legales de garantías de muy dilatada irradiación, como en los del artículo 56 del mismo D.F.L. N 126, de 1953, orgánico del Banco del Estado (DO. 186 de 24 de julio de 1953): "La hipoteca que se constituya a favor del Banco para caucionar un crédito concedido a través de este Departamento [Agrícola] garantizará todas las obligaciones directas o indirectas que el otorgante tenga o llegare a tener a favor de la Institución, a menos que conste expresamente que la hipoteca se ha constituido sólo en garantía de obligaciones determinadas o hasta concurrencia de un monto limitado"; y en el inciso $2^{\circ}$ del artículo 14 de la ley $\mathrm{N}^{\mathrm{o}} 3.379$ (DO. de 18 de mayo de 1918), modificada por el D.F.L. N 309 (DO. de 25 de julio de 1953): "El reintegro de estos fondos de retiro se garantizará con hipoteca de primer grado y esta misma garantía asegurará el pago del préstamo que la Caja efectúe para realizar la operación y cualquier otra deuda que el imponente contraiga en favor de la Caja". Como puede percibirse, en estos casos tampoco se dice que la hipoteca cuyo alcance es definido en cada norma, sea "general". A su respecto, vale lo dicho en la nota anterior.

${ }^{34}$ Rafael Mery Berisso, Derecho hipotecario. Estudio de Derecho civil chileno y comparado, Santiago, Editorial Jurídica de Chile, 1958, No 49, p. 108, quien acepta la de Riesco, que cita en la nota 30: es hipoteca con garantía general aquélla "en que el deudor hipoteca un predio como garantía, no sólo de la obligación que actualmente contrae, sino también de todas sus deudas futuras"; Somarriva Undurraga (n. 9), No 238, p. 221: mediante la cláusula de garantía general se "garantiza no sólo una obligación determinada, sino todas las que en el futuro por cualquier causa o motivo, llegue a contraer el deudor para con el acreedor"; UGARTE Godor (n. 15), p. 81: "Se llama cláusula de garantía general hipotecaria a aquella por la cual una hipoteca se constituye para caucionar cualesquiera obligaciones que una persona tenga al presente o pudiere tener en lo futuro por cualquier causa para con otra". La definición de nuestra cláusula con relación a la hipoteca es igualmente aplicable a la prenda sin desplazamiento.

${ }^{35}$ En algunos países europeos suele llamarse "ómnibus" ("para todas" [las obligaciones]) y también "globales" a estas garantías universales; y, aunque tales denominaciones estén lejos de impresionar por cierta elegancia, son correctas y equivale a lo que mienta el adjetivo 
es el acto, prenda en este caso, singular, cuya fuerza garantizadora queda circunscrita a las obligaciones que se han especificado e individualizado, y sólo a ellas, aunque sean muchas.

Diferente de ambas debe ser la garantía general, que resulta ser un intermedio entre las dos antes explicadas. Como su nombre lo indica, únicamente atañe a un género de obligaciones sin individualización ninguna determinada; pero excluye las que no pertenezcan al género descrito; y en ello se diferencia de la garantía universal; mas no queda limitada a ciertas obligaciones específicas, en lo cual se aparte de la especial. Esta prenda, pues, cauciona todas, pero sólo las obligaciones que pertenezcan al género descrito. Por cierto, pueden establecerse varios géneros. Tal ocurre, por ejemplo, si se da prenda para garantizar todas las obligaciones que nazcan de tales y cuales contratos de cuenta corriente, o de tales y cuales líneas de crédito, o de contratos de financiamiento de tales y cuales obras, etcétera.

En Chile, salvo que la ley la haya permitido expresamente, como de hecho acaece ${ }^{36}$, no puede valer una garantía universal, porque con ellas de suyo

i) queda vulnerado el artículo 1461 del $C C .:$ "No sólo las cosas que existen pueden ser objetos de una declaración de voluntad, sino las que se espera que existan; pero es menester que las unas y las otras [...] estén determinadas en cuanto a su género".

Por definición, una prenda en garantía universal de obligaciones no debe determinar las caucionadas ni siquiera por un género; $y$, al contrario, una prenda en garantía general de las mismas precisamente debe describir un género (o varios) de las mismas que cauciona y

ii) también queda vulnerado el carácter accesorio de toda garantía, exigido en especial para la prenda por el artículo 2385 del $C C$., porque una prenda universal, por definición, incluye obligaciones y fuentes de obligaciones en la actualidad no existentes y que no se sabe si en el porvenir habrán de existir o no.

\footnotetext{
“universal". Sobre ellas, véanse: Abel Veiga Copo, "Prenda 'omnibus', prenda rotativa de acciones y garantía flotante”, en Revista de Derecho Bancario y Bursátil, año 20, No 82, Madrid, 2001, especialmente pp. 35-43; Ángel Carrasco Perera, y otros, Tratado de los derechos de garantía, Navarra, Cizur Menor, Aranzadi, 2002, cap. $18^{\circ}$ : La hipoteca global y la hipoteca en garantía de la obligación de intereses, pp. 565-579, y cap. $25^{\circ}, \mathrm{N}^{\circ} 7$ "Prenda en garantía de una globalidad de obligaciones", pp. 830-831; Cinzia PISANI, "Pegno omnibus", en Paolo CENDON (a cura di), Il Diritto privato nella giurisprudenza. I Nuovi contratti nella prassi civile e commerciali, Torino, UTET., 2004, XIX: Garanzie, cap. $4^{\mathrm{o}}$, pp. 27-39.

${ }^{36}$ Véanse las prendas universales creadas por la ley $\mathrm{N}^{\circ} 4.287 \mathrm{y}$ el decreto con fuerza de ley $\mathrm{N}^{\circ} 126$, de 1953 , referidas en la nota 32 ; y las hipotecas del mismo carácter contenidas en las normas citadas en la nota 33.
} 
Así que es nula, por indeterminación de su objeto obligacional, la prenda de todas las obligaciones presente y futuras que el pignorante tenga o haya de tener para con el pignoratario por cualquier causa y en cualquier tiempo, y otras semejantes ${ }^{37}$. Pero la prenda en cuya convención se fija determinadamente una causa o fuente de obligación, sea presente, sea futura, y luego se haga extensiva su garantía a todas las obligaciones presentes o futuras provenientes de la causa o fuente fijada, es general y vale. En el entendido de no confundirse obligación futura con obligación posible.

b) Por obligación futura se entiende la que actualmente no existe, pero se espera que exista. Con ello hacemos nada más que aplicar el concepto de cosa futura, conocido por el Código Civil, a las obligaciones, que, después de todo, son una especie de cosas, aunque incorporales (artículo 576 del $C$ C.). La regla general viene sentada por el inciso $1^{\circ}$ del artículo 1461 del $C C$. .: "No sólo las cosas que existen pueden ser objetos de una declaración de voluntad, sino las que se espera que existan [...]". Las que existen son cosas presentes; y futuras las que se espera que existan. En aplicación de esta doctrina, el propio Código declara válidos el legado de cosa futura (artículo 1113 del CC.), la compraventa de cosa futura (artículo 1813 del $C C$.), la fianza de obligación futura (artículo 2339) y la hipoteca de bienes futuros (artículo 2419 del CC.); y, en determinadas condiciones, hace responsable al donatario a título universal por las deudas futuras del donante, frente a sus acreedores en los mismos términos que los herederos (artículo 1418 del $C C$.). También prohíbe algunos negocios de la clase que tratamos, como los pactos sucesorios sobre sucesión futura (artículo 1204 del CC.; cfr. con el artículo 1204 del CC.). Así que cuando aplicamos las definiciones del inciso $1^{\circ}$ del artículo $1461 \mathrm{del} C C$. resulta que no sólo las obligaciones que existen pueden ser objetos de una declaración de voluntad prendaria sino las que se espera que existan. Ahora bien, la posibilidad de pignorar sin desplazamiento en garantía de obligaciones futuras está expresa y directamente consentida por el artículo 4 de la ley: "Podrán caucionarse con esta prenda cualquier clase de obligaciones, presentes o futuras $[\ldots] "$.

Entre las principales obligaciones futuras se cuentan las sometidas a condición suspensiva. Lo propio de un acto suspensivamente condicionado es posponer el nacimiento de la obligación que ese acto es idóneo para generar, de modo que aquélla no existe mientras la condición penda; pero

${ }^{37}$ En plena congruencia con el repudio generalizado que el Código fulmina a los actos universales, que no sean las asignaciones por causa de muerte a título universal. Véanse los artículos 1407 del CC. (que exige inventario solemne de los bienes universalmente donados, con lo cual convierte al acto en singular, porque sólo se aplica a los que aparezcan en el inventario); 1811, que anula la venta universal; y 2056, que prohíbe la sociedad universal. 
es manifiesto que se espera que exista o que puede preverse su existencia, por más que, si la condición falla, no vaya a existir.

También son obligaciones futuras las programadas para un tiempo posterior en un precontrato o contrato preparatorio, como la que haya de nacer de la compraventa concreta que se hizo objeto de una promesa de ese contrato: aunque en virtud de ésta el promitente comprador no debe el precio de la compraventa, por ahora meramente prometida, se espera que haya de deberlo una vez celebrada ella; pero se la puede caucionar de antemano.

Son obligaciones, asimismo, futuras las que en el porvenir pueden derivarse de una actual responsabilidad contraída. Así, por ejemplo, del que administra bienes ajenos, como un tutor, un curador o un mandatario, o el que los tiene en uso, como el comodatario o el arrendatario; o custodia, como el depositario; o en uso y goce, como el usufructuario (usuario y habitador): o en mera y pura tenencia, como el pignoratario civil o comercial. Todas estas personas contraen responsabilidad por la pérdida o el deterioro de la cosa que tienen, la cual, cuando se produce un daño imputable a su culpa (en diversos grados según el acto básico) o dolo y aun por caso fortuito en determinadas circunstancias, como después de la mora, su responsabilidad se actualiza en una concreta obligación de indemnizar. Esta obligación no existe mientras el daño no se produzca, pero como podría producirse $-\mathrm{y}$ tanto, que está previsto y regulado en sus efectos por la ley-, de ella cabe decir que se espera que exista en términos objetivos -lo cual es muy distinto a decir que se desea-; así que constituye obligación futura.

En general, este último concepto se identifica con una spes obligationis ("esperanza de obligación"), pero concreta, o sea, derivada de alguna operación de la que pueda estimarse haber de nacer una obligación, independientemente de que nazca o no después.

c) Por obligación posible se entiende la que actualmente no existe y cuya existencia no se espera, mas que puede de forma indeterminada llegar a existir alguna vez en el porvenir, aunque también podría no llegar a existir, sin que haya alguna operación jurídica que permita esperar que haya de existir. Su diferencia con la obligación futura, por ende, radica en el segundo punto de los tres mencionados: mientras de la futura se espera su existencia, no acaece lo propio en la posible. Así que obligación posible es la que alguna vez podría existir, aunque también no existir. Se comprende que una obligación puramente posible pertenece al campo de la indeterminación más absoluta, y una obligación así ocupa el mismo rango de todo lo que en el mundo puede acaecer, en el sentido ordinario de la expresión "todo es posible". Cualquier persona, en efecto, puede en el porvenir llegar a contraer obligaciones a muy diversos títulos, con respecto a muchas personas, posibles acreedoras, o a una o algunas que se quiera indicar. Por 
ejemplo, todos están expuestos a causar algún daño a personas o a cosas ajenas, debido a alguna maniobra culpable en la conducción de un automóvil. Pero nada hay que permita esperar que la pertinente obligación de indemnizar haya de nacer; ésta es, por ende, posible, pero no futura. Una vez provocado efectivamente el daño, la obligación de indemnizar empieza a ser futura, porque si hay condena judicial, el autor quedará obligado ${ }^{38}$.

De lo dicho deriva que una prenda en garantía general no cubre las obligaciones meramente posibles; extenderla a ellas también implica vulnerar la determinación o determinabilidad exigidas para el objeto de toda declaración de voluntad por el artículo 1461 del $C C$.; y el carácter accesorio de la prenda impuesto por su artículo 2388, incluso referido, como hemos hecho aquí, a la fuente de las obligación y no a la obligación misma, porque una obligación meramente posible implica una fuente meramente posible; y una tal fuente no es la principal exigida por aquella disposición.

e) El artículo 4 de la ley, empero, dice algo que acaso pudiere ser invocado para contradecir nuestras conclusiones acerca de la garantía universal. Se lee ahí: "Podrán caucionarse con esta prenda cualquier clase de obligaciones, presentes o futuras, estén o no determinadas a la fecha del contrato". La última frase de este texto, pues, ofrece la posibilidad de constituir prenda por obligaciones "no determinadas a la fecha del con190 trato" 39 . Ahora bien, la eventual indeterminación que interesa de una obligación no sólo puede ser en cuanto a su monto más, también, en cuanto a su origen o fuente ${ }^{40}$.

Cuando la expresión legal la referimos a la indeterminación en cuanto al monto de la obligación, con tal manera de expresarse la ley no alude solo ni necesariamente a la prenda en garantía general. Puede, en efecto, constituirse prenda en garantía especial por alguna obligación no determinada en su monto a la fecha de la convención, como si alguien, que reconoce haber cometido cierto delito o cuasidelito concretos, constituye prenda para caucionar el pago de la indemnización que acuerde en el futuro con la víctima o que fije el tribunal; y, más ampliamente, en la prenda de cualquier obligación específica, cierta en su existencia e incierta en su monto, tales cuales suelen ser las de responsabilidad ${ }^{41}$ y las de hacer y no

${ }^{38}$ En cierto sentido, las obligaciones futuras son también posibles, aunque la inversa no es válida. Pero es mejor no tomar aquello en cuenta para no oscurecer los conceptos involucrados.

${ }^{39}$ Se observará que el carácter determinado o indeterminado se predica tanto de las obligaciones presentes como de las futuras. Por consiguiente, no son sinónimas las obligaciones futuras y las indeterminadas, como a veces se ha pensado.

${ }^{40}$ Puede haber otras indeterminaciones, como en cuanto al plazo, que no interesan en materia prendaria.

${ }^{41}$ Así, por ejemplo, en la de sanear los vicios redhibitorios o la evicción. 
hacer, respecto de las que puede ser necesario evaluar. Al revés, puede haber una prenda en garantía general de obligaciones determinadas en su monto, como si se la constituye por todas las que deriven de un contrato de línea de crédito, cuyo monto máximo acreditado -según suele ser de hecho- ha sido fijado en determinada cantidad, porque la restitución de éste es lo garantizado, aunque se lo divida en montos parciales no determinados. Con todo, es verdad que, con mucha frecuencia, las obligaciones caucionadas con prenda general son de monto indeterminado. Lo cual pasa a ser regla en las garantías universales. Está claro, por consiguiente, que la dicción legal en comento cubre esas clases de prenda, aunque no ataña exclusivamente a ellas ${ }^{42}$.

Cumple ahora examinar, si la expresión legal: "estén o no determinadas a la fecha del contrato" incluye una indeterminación concerniente al origen o fuente de la obligación; vale decir, si es posible una prenda para unas obligaciones que a la fecha de la convención no se conozca cuáles sean o hayan de ser sus orígenes o fuentes. Desde luego cabe excluir esa posibilidad cuando se la quisiere aplicar a una prenda especial, porque sería contradictoria con el concepto mismo de tal prenda. Ésta consiste en garantizar obligaciones específicas e individualizadas; ahora bien, una obligación cuyo origen o fuente no se conoce, no puede ser especificada o individualizada. Por consiguiente, no queda más que aplicarla a la garantía general. En tal caso, y atendido que la indeterminación de que habla el artículo 4 sin duda atañe al monto de la obligación, en la prenda general y especial, conceptualmente habría él de expresar lo que sigue para incluir también la indeterminación acerca de la fuente en la garantía general:

"Podrán caucionarse con esta prenda cualquier clase de obligaciones, presentes o futuras, estén o no determinadas en cuanto a su monto cuando la garantía es especial o general y estén o no, además, determinadas en cuando a su origen cuando es general, a la fecha de la convención".

Si así lo dijera realmente, cesaría la discusión; pero no lo dice. Por consiguiente, el intérprete tendría que asignar dos significados distintos a un mismo vocablo empleado una única vez con certeza en una de sus significaciones; lo cual es inadmisible, porque atribuir dos significados a un vocablo es lo mismo que interponer dos palabras distintas, una para cada significado.

${ }^{42}$ De esta manera, la repulsa de la prenda universal sin desplazamiento no puede fundarse en ser indeterminadas en cuanto a su monto las eventuales obligaciones que ella garantiza. 
Por si lo anterior pudiere parece demasiado dialéctico, aponemos este otro argumento, estrictamente jurídico. La idea de que puede haber una prenda para obligaciones cuyas fuentes se desconocen a la fecha de la convención, vale decir, que están indeterminadas a ese respecto, es una transgresión directa de la regla fijada por el artículo 2385 del $C C$. "El contrato de prenda supone siempre una obligación principal a que accede". Puesto que la regla habla de "obligación", queda implicada su fuente, sin la cual no puede existir (arg. ex artículo 1437 del $C$ C.); así que ella dice al mismo tiempo: "El contrato de prenda supone siempre una fuente de obligación principal a que accede". Pero una prenda constituida para obligaciones cuyas fuentes no se conocen, ya no supone una fuente de obligación a la que acceda; y entonces la regla queda infringida. Ahora bien, ella, que fue formulada en el Código Civil para la prenda con desplazamiento, igualmente rige la prenda sin desplazamiento, por mandato del último segmento del artículo 1 de la ley. En tales circunstancias, no cabe interpretar la palabra 'indeterminadas' de su artículo 4 como alusiva a una indeterminación en cuanto al origen o fuente de la obligación, sino sólo como alusiva a una indeterminación en cuanto a su monto, lo que es plenamente aceptable.

Con lo anterior no queda dicho que la prenda sin desplazamiento no pueda ser constituida como general. Que puede serlo, lo expresa sin am192 bigüedad el artículo $3 \mathrm{~N}^{\circ} 2$, que es la base primera de nuestras actuales indagaciones. Lo único que queda dicho es que una garantía general no debe consistir en la caución de obligaciones cuyo origen o fuente está indeterminada.

\section{Segunda mención (continuación): \\ Referencia a los documentos en que consten las obligaciones garantizadas como sustitución de la indicación de las obligaciones caucionadas}

El segundo segmento del $N^{o} 2$ del artículo 3 está redactado de tal forma, que resulta permitido deducir que la "indicación de las obligaciones caucionadas", fundante de una garantía especial según el mismo número, puede ser sustituida por una referencia o indicación a los documentos en que consten las obligaciones garantizadas.

a) Esto significa que la norma se pone en la alternativa de que la convención prendaria conste en una escritura pública o en un documento privado con firmas autorizadas antes un notario y protocolizado, y que el acto principal del que dimane o haya de dimanar la obligación garantizada conste aparte en otros documentos. Dice, en efecto: "En caso que sólo se refieran los documentos donde constan las obligaciones garantizadas y éstos [...]". La ley no repudia la aludida sustitución, como lo da a entender el adverbio 'sólo' que emplea ("En caso que sólo se refieran”), con el 
cual, evidentemente, se quiere decir que es posible referir los documentos y únicamente ellos.

Pero corrobora definitivamente tal interpretación el texto del artículo 24 de la ley, ya estudiado para otros efectos, que, en su parte pertinente, dice:

"Dentro del plazo de tres días hábiles [...] el notario deberá enviar para su inscripción en el Registro de Prendas sin Desplazamiento, una copia autorizada del contrato de prenda [...] y una copia de los documentos en que consten las obligaciones garantizadas que se hubieren protocolizado en su registro, si éstas no estuvieren indicadas precisamente en el contrato de prenda”.

Con la expresión "una copia autorizada del contrato de prenda" la ley alude a una copia así, bien de la escritura pública, bien del instrumento privado con firmas autorizadas ante notario y protocolizado, según la alternativa dada por su artículo 2, antes estudiado. Con "una copia de los documentos en que consten las obligaciones garantizadas que se hubieren protocolizado en su registro", en cambio, apunta a la hipótesis de sustitución que ahora indagamos, contenida en el segundo segmento del artículo 3 No 2: "En caso que sólo se refieran los documentos donde constan las obligaciones garantizadas [...]", documentos que después, como veremos, la misma norma ordena protocolizar en su caso. Ahora bien, el artículo 24 describe la protocolización, que supone, bajo la condición de que las obligaciones garantizadas ("éstas") "no estuvieren indicadas precisamente en el contrato de prenda". Lo cual implica que no necesariamente deben estar indicadas ahí.

Esta opción dada por la ley es del todo lógica. Es propio de la garantía especial individualizar las obligaciones que se caucionan con ellas. Pero una manera correcta de hacerlo es referir el documento en que consta cada una. Así que, en realidad, la referencia a los documentos propiamente hablando no constituye un alternativa u opción a la indicación de las obligaciones caucionadas, sino una forma específica de indicarlas.

Por cierto, la referencia a los documentos tiene que estar formulada con tanta especificidad cuanta sea necesaria para individualizarlos completamente.

Por su parte, las obligaciones que se caucionen deben estar individualizadas en los documentos aparte, en cuanto a su origen o fuente, monto, plazo e interés, de acuerdo con lo concluido en la letra b) del número 3 del presente capítulo; y no es suficiente una referencia genérica ni ambigua.

b) Pero cuando, para indicar las obligaciones especialmente caucionadas, se emplea el procedimiento de referir los documentos en que ellas constan, la ley añade una nueva formalidad externa. La segunda parte completa del $\mathrm{N}^{\mathrm{o}} 2$ del artículo 1 dice: 
"En caso que sólo se refieran los documentos donde constan las obligaciones garantizadas y éstos no estuvieren incorporados en un registro público, deberán ser protocolizados en copia simple al momento de la celebración del contrato de prenda”.

Así, pues, cuando las partes, para individualizar las obligaciones caucionadas y así dar lugar a una prenda especial, escogen la fórmula de referir los documentos en que ellas constan, una de dos: o tales instrumentos se encuentran a la sazón incorporados en algún registro público o no están incorporados en ninguno de tales.

c) En el primer caso, aunque la ley nada expreso diga, es, con todo, necesario individualizar en la convención los datos de la incorporación preexistente, porque ellos forman parte de la operación de referir "los documentos donde constan las obligaciones garantizadas". La previa incorporación en un registro público no necesariamente es en el registro público de un notario; y con su manera de expresarse la ley alude a cualquier repositorio de documentos por incorporación que tenga carácter público, no en el sentido de estar abierto al público, aunque sea en sí mismo privado, sino en el sentido de estar ordenado por la ley y puesto a cargo de un oficial o de un funcionario público.

En especial, deben ser recordados que son documentos incorporados en un registro público:

i) los documentos protocolizados en el registro de algún notario, pues, por definición, ellos quedan "agregados", es decir, incorporados en él (artículo 415 inciso $1^{\circ}$ del COT.). El notario en cuyo registro había sido ejecutada la protocolización no tiene por qué ser el mismo ante el cual después se firma la escritura pública de la convención de prenda o el mismo quien después autoriza las firmas del instrumento privado que lo formaliza: una conexión necesaria entre ambos notarios no está ni remotamente mandada por la ley, ni se deduce de ninguna otra prescripción ni tampoco está exigida por la naturaleza del procedimiento, ni siquiera a título de seguridad, cautela o resguardo;

ii) también tienen el aludido carácter las escrituras públicas, porque, por su propia solemnidad, ellas deben ser incorporadas en el protocolo o registro público de un notario (artículo 403 del COT.). Pero hay otros casos. Un buen ejemplo

iii) es el de los documentos sobre la base de los cuales se ejecuta la inscripción de los vehículos motorizados en el Registro Nacional de Vehículos Motorizados que gestiona el Servicio de Registro Civil e Identificación. La ley ordena que tales documentos sean incorporados en el Archivo Nacional de aquel servicio ${ }^{43}$.

${ }^{43}$ Ley $\mathrm{N}^{\circ} 18.29$ (DO. de 7 de febrero de 1984), artículo 34 inciso $3^{\circ}$ : "La inscripción de un vehículo se efectuará al otorgarse la patente única. Los documentos que autoricen 
$\mathrm{Si}$, por consiguiente, en cierto documento que es título de adquisición de algún vehículo consta, además, la obligación de pagarlo y basado en él se procedió a su inscripción en el Registro Nacional de Vehículos Motorizados y a su consiguiente incorporación en el Archivo Nacional del Servicio de Registro Civil e Identificación, y se confiere prenda sin desplazamiento para la obligación del pago de su precio, en la pertinente convención prendaria esa obligación puede ser indicada merced a una referencia al documento incorporado en el dicho Archivo Nacional, sin necesidad de su protocolización en el registro del notario.

d) En el segundo caso, de no estar incorporados en algún registro público los documentos obligacionales referidos en la convención prendaria especial, la disposición en examen ordena que una copia simple de cada uno de los documentos en que conste la obligación que se cauciona sea protocolizada al momento de la celebración de la convención de prenda. Esta operación debe hacerse en el protocolo del mismo notario ante el cual se suscribe la escritura pública de la convención o se autoriza las firmas de las partes estampadas en el documento privado que lo contiene y no, pues, en el de otro notario, porque la norma exige que la protocolización sea hecha "al momento de la celebración del contrato de prenda": como la celebración de esta convención siempre tiene lugar ante un notario, sea éste aquél ante quien se otorga la escritura pública, sea aquél que autoriza las firmas del instrumento privado, la única manera de que la protocolización sea hecha "al momento de la celebración del contrato de prenda" es que ella sea hecha por el mismo notario del contrato en el momento de éste; si es hecha por otro, aunque por coincidencia (bien difícil, por lo demás) haya sido practicada simultáneamente, aun así, de hecho no será ejecutada "al momento" de la celebración del contrato, sino en un momento conceptualmente distinto del momento del contrato. Con la expresión 'al momento', la ley exige la unitas actus y ésta pide, entre otras cosas, unidad de notario. Por lo mismo, la protocolización no puede tener lugar después del momento en que se celebró la convención. Cuando es ejecutada antes de celebrada aquélla, la situación transita al primer caso, de estar ya incorporado en un registro público el documento que es referido.

e) La norma sólo exige que lo protocolizado sea una "copia simple" del documento donde consta la obligación garantizada. Que sea una "copia" significa que no es necesario que se trate del original del documento y basta su reproducción, siempre que sea fiel, pues de lo contrario no es copia. Que sea "simple” también indica no ser necesario que consista en una "autorizada". Una "copia autorizada" es aquélla librada por la auto-

dicha inscripción serán incorporados en el Archivo Nacional del Servicio de Registro Civil e Identificación”. 
ridad de algún funcionario u oficial público, frecuentemente un notario. Así que una "copia simple" basta que sea una copia sin que le sea, además, exigible la autorización de ningún funcionario u oficial públicos en cuanto copia. El documento original, de cuya copia se trata, en cambio, puede ser público, oficial o privado.

f) El artículo 30 continúa con estas palabras: "Si en el contrato de prenda no se indica la obligación caucionada, para proceder a la ejecución deberá acompañarse un título con mérito ejecutivo en el que conste dicha obligación [...]". En esta parte, la disposición ahora alude a la prenda en función de garantía general. Es nuevamente congruente con el artículo 3 $\mathrm{N}^{\mathrm{o}} 2$, que ofrece como alternativa de menciones forzosas la "indicación de las obligaciones caucionadas o bien de que se trata de una garantía general". El artículo 30 precisamente pone la hipótesis negativa de no haberse indicado las obligaciones caucionadas, lo cual significa que piensa en la hipótesis positiva de tratarse de una garantía general. De acuerdo con la naturaleza de tal garantía, exige añadir al documento de la convención un título con mérito ejecutivo en que conste la obligación específica por cuyo incumplimiento el acreedor quiere realizar la prenda, ya que el señalamiento en la convención, del género de obligaciones para las que se constituyó, no es suficiente. Pero lo que sigue, porque atañe a la ejecución, 196 ya no nos interesa aquí.

\section{Tercera mención:}

La individualización o caracterización de las cosas empeñadas

La tercera mención ordenada por el artículo 3 consiste en una "individualización o caracterización de las cosas empeñadas".

a) En tema de cualquier prenda, la regla general es que ella ha de recaer sobre cosa no fungible, única manera de poder ser ésta perseguida merced al derecho real que se confiere al pignoratario ${ }^{44} ; \mathrm{y}$, con respecto especial a la prenda sin desplazamiento, única manera de que se puedan tipificar algunos delitos previstos por la ley en el artículo 39, como el del su número 2:

"El deudor prendario y el que tenga en su poder la cosa constituida en prenda en conformidad a esta ley que, defraudando al acreedor prendario, la altere, oculte, sustituya, traslade o disponga de ella";

${ }^{44}$ En el caso de la prenda con desplazamiento, se añade que tal exigencia asegura que el pignoratario devuelva la misma cosa que recibió (artículo 2401 del $C C$.) y que no pueda consumirla (artículo 2395 del $C$ C.). De recaer sobre fungibles, el pignoratario podría disponer la cosa y después reponerla. 
pues de lo contrario, el pignorante podría impunemente sustituir los objetos fungibles que empeñó por otros de su mismo género y calidad, o disponerlos y después reponerlos.

Ésta es la base dogmática de la exigencia establecida en el artículo 3 $\mathrm{N}^{0}$ 3. Puesto que la prenda sin desplazamiento también debe recaer sobre cosas no fungibles, eso en una convención que no las determina por el acto de su entrega, sino por un consenso de cosas que no tienen por qué estar presentes debe reflejarse precisamente en la necesidad de su "individualización o caracterización" en la misma convención escrita. Ella se cumple cuando se describen las cosas pignoradas de tal modo que no deje en duda, ambigüedad u oscuridad las cosas que fueron pignoradas, de modo de no saberse en qué y cuáles cosas recayó la convención. Acerca del modo de ejecutar la individualización o caracterización nada dice la ley; así que deberá procederse a ellas en la manera que sea, con tal que se cumpla el objetivo dicho. De hecho, los usos del comercio tienen modos seguros de individualizar o caracterizar, por la marca, el modelo, cierto código estampado o impreso, etcétera.

b) Hay ciertos objetos pignorables sin desplazamiento que imponen una modalidad a la regla precedentemente examinada. El inciso $1^{\circ}$ del artículo 11 de la ley autoriza la pignoración de "grupos de bienes de una misma clase o universalidades de hecho, tales como existencias, inventarios, materias primas, productos elaborados o semielaborados o repuestos, o maquinarias, redes o sistemas" ${ }^{45}$. Ahora bien, con persistente frecuencia estos objetos son fungibles, porque consisten en cosas que la naturaleza o la industria humana generan en serie. Con respecto a ellas, puede ser muy difícil sino imposible su individualización o caracterización, que no sea por el lugar de su depósito, que sí puede ser individualizado. Pero acaece que la ley permite, salvo pacto en contrario, utilizar, reemplazar, transformar o enajenar estos objetos al pignoratario (artículo 11 inciso $\left.1^{\circ}\right)$ y en tal caso el lugar preciso de su localización o depósito pierde su función individualizante. En realidad, la prenda de grupos de bienes de una misma clase o universalidades de hecho está pensada para establecer un flujo constante de egresos e ingresos de las especies componente del conjunto, de modo que las egresadas dejen de estar en prenda y las ingresadas empiecen a estarlo. Como en circunstancias normales este flujo hace permanecer una masa constante de especies en el interior del conjunto, aunque no corresponda a la existente en el momento de la pignoración,

${ }^{45}$ Sobre la prenda de estos objetos, véase: Alejandro GuzMán BRITo, "La pignoración de grupos de bienes de una misma clase o universalidades de hecho en la nueva 'ley de prenda sin desplazamiento"', en Revista de Derecho de la Pontificia Universidad Católica de Valparaíso, $\mathrm{N}^{\mathrm{o}} 30$, Valparaíso, ${ }^{\mathrm{er}}$ semestre de 2008, pp. 61-153. 
es en esa masa fluida en la que recae la prenda; lo cual es consecuencia de tratarse de universalidades. Porque, dogmáticamente hablando, lo pignorado no son las especies sino el conjunto mismo, con independencia de sus componentes individuales. Por consiguiente, cuando se dice que la prenda debe recaer sobre infungibles, eso debe entenderse con respecto al conjunto y no a sus individuos, que pueden ser fungibles; así que la exigencia refleja de individualización o caracterización de las cosas empeñadas significa la exigencia de lo propio con respecto al conjunto, vale decir, del grupo de bienes de una misma clase o la universalidad de hecho sobre la que recae la convención. Es uno u otra el que debe ser individualizado o caracterizado. Supóngase que se pignora la universalidad constituida por automóviles nuevos de tal marca, modelo y año. Estos objetos son fungibles entre sí y con respecto a otros automóviles de sus mismas características. El conjunto mismo es también fungible, porque puede ser confundido e intercambiado con otros conjuntos de automóviles de iguales apariencias. Mas cuando se lo describe como "conjunto de automóviles de tal marca, modelo y año sito en tal bodega", la fungibilidad del conjunto desaparece, aunque sus componentes mantengan el carácter de fungibles. Por consiguiente, la individualización o caracterización de estos conjuntos se ejecuta merced a la constancia de las características genéricas de sus componentes, pero no de las individuales, como los números de motor o de las patentes de circulación, si los tienen, más un añadido especificador del conjunto mismo. En el ejemplo, tal añadido es el lugar en el que el conjunto original estuvo guardado; el cual determina que todo lo que actualmente esté ahí se encuentra bajo la prenda. La necesidad de abstenerse de señalar las características individuales de los componentes es para evitar que la prenda del conjunto se convierta en prenda de esos componentes individuales $\mathrm{y}$, dejando de serlo de un conjunto, devenga en prenda de muchas cosas.

c) Algo semejante acaece en la pignoración de derechos administrativos de concesión y muebles conexos, previstos por el artículo 6. En sus números 1, 2, 4, 5 y 6 se autoriza la pignoración sobre los "ingresos o flujos futuros que provengan de la explotación de la concesión" pignorada; con lo cual se alude, a final de cuentas, a dinero, el bien más fungible que puede concebirse; así que su individualización exige la diferenciación, determinación y especificación muy precisa del flujo mismo en cuanto a su origen, modos de producirse y canales de producción y de la cantidad eficaz de circunstancias que cumplan la exigida "individualización o caracterización" de las cosas empeñadas. 


\section{Cuarta mención:}

Limitación de la prenda a una suma o a una proporción de diversas obligaciones. Remisión

El artículo 3, en su $\mathrm{N}^{\mathrm{O}} 4$ formula todavía una cuarta mención: "La suma determinada o determinable a la que se limitare la prenda o la proporción en que debiere caucionar diversas obligaciones, si fuere el caso"; pero ella no es, en realidad, forzosa sino opcional; así que la trataremos entre las de esta clase ${ }^{46}$.

\section{Sanción por la inobservancia de las solemnidades internas}

Todavía nos resta un punto por examinar. Atañe él a las sanciones procedentes por la transgresión del artículo 3 de la ley, cuyo estudio hemos terminado. Él no las señala, así que deberemos determinarlas por aplicación de las reglas generales.

Las menciones exigidas por el artículo 3 son, como ya quedó dicho, forzosas, porque éste dice que la convención "deberá" contenerlas. No pueden, pues, ser omitidas. Si es así, resulta que constituyen requisitos o formalidades que la ley prescribe para el valor de la convención. Como, por otro lado, el requisito de las menciones descritas por el artículo 3 va establecido en consideración a la naturaleza de la convención y no a la calidad o estado de las personas que intervienen en ellos, su omisión es la nulidad absoluta (artículo 1682 inciso $1^{\circ}$ del $C C$.).

El examen de las transgresiones a cada mención exigida hará ver mejor aún que no en otra que la dicha nulidad puede consistir su sanción.

a) $\mathrm{Si}$ en el documento de la convención prendaria no aparece la individualización de sus otorgantes (artículo $3 \mathrm{~N}^{0} 1$ ), dejando a un lado el carácter extraordinario y casi absurdo de la hipótesis -por no decir virtualmente imposible, dado que el notario no firmará la escritura pública de la convención ni autorizará las firmas del instrumento privado que lo porte, si en uno u otro documento no van individualizadas sus partes-, ello sólo puede ser debido a que las partes que realmente lo otorgaron omitieron su individualización o a que la convención no tuvo partes, y su ausencia real se reflejó en la ausencia de una individualización (que hubiera sido ficticia); lo cual implica haber forjado alguien la convención y ser, por ende, falsa. En el primer caso, aunque la convención, en una fase puramente consensual anterior a su formalización, tuvo a dos personas existentes como candidatas - por así llamarlas- a ser partes del acto solemne, y éste no las individualizó como la ley ordena, se ha faltado a un requisito que ella prescribe para el valor del acto y, por ende, cae en nulidad absoluta.

${ }^{46}$ Véase, más adelante, el cap. XI, 1. 
En el segundo caso, con independencia de la falsedad de la convención, que por sí mismo es hipótesis de nulidad por falta de consentimiento, la ausencia de individualización genera el mismo razonamiento y la misma conclusión que en el primero.

El defecto de la individualización de los terceros que concurran a la convención prendaria en cuanto tales no genera la nulidad de aquélla, aunque pueda provocar la nulidad en la convención anexa que se le incorpora.

b) Si en el documento prendario no se indican precisamente, en el modo legal, las obligaciones caucionadas ni que es en garantía general la prenda contraída, la nulidad absoluta que se genera puede fundarse, sin más, en el mismo punto de faltar un requisito prescrito por la ley para el valor del acto; pero, además, en esta otra consideración: la prenda, atendido su carácter subsidiario, tiene, no uno sino dos objetos acumulados: la cosa sobre la que se constituye garantía y la obligación en garantía de la cual se la constituye. Si no se indican las obligaciones caucionadas, falta uno de sus objetos; y la ausencia de objeto en un acto jurídico es causa de su nulidad absoluta. Por cierto, puede acaecer que haya habido obligación o pacto de garantía general, y que uno u otro hayan sido omitidos en el documento. Pero la real existencia de uno de aquellos extremos no puede ser alegada ni probada, si faltó el documento de solemnidad en el cual la $200 \quad$ ley ordena que consten.

Puede acaecer que las partes indiquen expresamente ser especial la prenda y describan un género de obligaciones como caucionadas, lo que hace pensar en ser aquélla general o, bien, que declaren ser general la prenda y describan obligaciones específicas y determinadas como caucionadas, lo que hace pensar en haber sido convenida como especial. En ambos casos hay discordancia entre el carácter abstractamente atribuido a la prenda y la extensión concreta del objeto obligacional caucionado. La solución es diferente según el caso. Si las partes determinaron y especificaron ciertas obligaciones como caucionadas y declararon ser general la garantía, sin describir consecuentemente un género de obligaciones además, al cual aplicarla, la convención vale sólo como de garantía especial para las obligaciones especificadas. Ello, porque se cumplen los requisitos de esta última, mas no los de la primera. $\mathrm{Si}$, en cambio, las partes describieron un género de obligaciones como caucionadas y dijeron que la prenda es especial, no vale la convención, porque, según la ley, la garantía general debe ser expresa.

c) Cuando en los documentos prendarios faltan la individualización o caracterización de las cosas empeñadas, teniendo presente que constituyen el otro objeto de la convención prendaria, la convención es nula por falta de objeto o por indeterminación del mismo. 
VIII. CAPACIDAD, OBJETO Y CAUSA

DE LA CONVENCIÓN PRENDARIA

\section{Capacidad para convenir y facultad de disponer de la cosa pignorada}

La convención prendaria no está sujeta a normas propias sobre capacidad de ejercicio para celebrarla, así que se rige por las generales sobre la materia.

Para la validez de la convención no se exige que la persona capaz de convenir, según tales reglas generales, deba, además, tener facultad de disposición sobre la cosa mueble que declara pignorar, vale decir, que sea su dueño. Dicho lo mismo de otra manera, la convención prendaria sobre cosa ajena vale ${ }^{47}$. Esta proposición deriva de lo establecido por el artículo 13, cuyo inciso $1^{\circ}$ reza así: "Sólo el dueño podrá alegar la inexistencia del derecho real de prenda invocando su derecho de dominio sobre la cosa pignorada, sin perjuicio de la validez del contrato". La norma no contiene expresamente la hipótesis de una pignoración de cosa ajena; pero la da por supuesta cuando reserva en forma exclusiva al dueño la invocación de propiedad sobre la cosa pignorada, porque ello implica que no fue él quien la empeño, sino un tercero. Si tal acaece, el inciso en examen trata del efecto de una pignoración de cosas ajenas con respecto al derecho real ${ }^{48} \mathrm{y}$ con respecto a la convención. Aquí nos interesa este último extremo, acerca del cual el último segmento del artículo 13 declara manifiestamente que el contrato (es decir, la convención prendaria) tiene validez, pese a recaer en cosa ajena al pignorante.

Por lo demás, eso no es diferente, en principio, de cuanto expresa el primer segmento del artículo 2390 del $C C .:$ "Si la prenda no pertenece al que la constituye, sino a un tercero que no ha consentido en el empeño, subsiste sin embargo el contrato, mientras no la reclama su dueño [...]”. El artículo 13 es más enfático: el dueño puede alegar el dominio sobre la cosa pignorada y, por ende, reclamarla, pero "sin perjuicio de la validez del contrato". La diferencia se debe a que el Código Civil habla de un contrato real; así que reclamada la cosa por su dueño y recuperada por él, aquélla pasa

${ }^{47}$ Sobre lo que sigue: Alejandro Guzmán BRito, "Las prendas ordinarias y sin desplazamiento de la ley No 20.190 recaídas en cosa ajena”, en Fabricio Mantilla EsPinOza - Carlos Pizarro Wilson (coordinadores), Estudios de Derecho Privado en homenaje a Christian Larroumet, Santiago - Bogotá, Fundación Fernando Fueyo - Universidad Diego Portales Universidad del Rosario, 2008, pp. 401-422.

${ }^{48} \mathrm{El}$ artículo 2387 del $C C$.: "No se puede empeñar una cosa, sino por persona que tenga facultad de enajenarla", se refiere al derecho real de prenda, aunque en la prenda civil la perfección del contrato y la constitución del derecho real provengan de la entrega; lo que no acaece en la prenda sin desplazamiento, donde se distinguen y separan la convención prendaria y la constitución del derecho real; así que la disposición citada es aplicable a ésta en lo relativo al derecho real, más no a la convención. 
del pignoratario al dueño y ya no hay más contrato, es decir, no subsiste. La ley $\mathrm{N}^{\circ} 20.190$, en cambio, habla de una operación que no ha implicado el desplazamiento de la cosa al pignoratario, así que el dueño la reclama al pignorante (o a un tercero); y cuando la obtenga, la convención, en sí misma, no se ve afectada porque no dependió de que su objeto estuviera en manos de persona determinada. De esta manera, ella puede subsistir para seguir regulando las relaciones entre el pignorante y el pignoratario ${ }^{49}$.

Pero debe recordarse que la constitución de prenda sobre bienes ajenos como propios de todos modos se tipifica como delito, según la previsión del artículo 39: "Serán castigados con las penas señaladas en el artículo 473 del Código Penal:/ 1) El que defraudare a otro [...] constituyendo prenda sobre bienes ajenos como propios [...]"; siempre, por supuesto, que confluyan en la acción los elementos generales de todos delito, como el dolo o la antijuridicidad, etcétera.

\section{Objetos}

En toda prenda hay dos objetos: aquél consistente en la cosa que es afectada a garantía y aquél pertinente a la obligación que es garantizada. En esta ocasión, nos limitaremos a dar las indicaciones generales que emanan de la 202 ley sobre estos objetos, sin entrar en su estudio particular que aumentaría excesivamente el volumen del presente escrito. Por lo demás, con respecto a algunos, ya existen trabajos especiales ${ }^{50}$.

${ }^{49}$ El segundo segmento del artículo 2390 añade: “[...] (subsiste sin embargo el contrato), mientras no la reclama su dueño; a menos que el acreedor sepa haber sido hurtada, o tomada por fuerza, o perdida, en cuyo caso se aplicará a la prenda lo prevenido en el artículo 2183". Este último, por su lado, dispone: [Inc. $1^{\circ}$ ] "El comodatario no tendrá derecho para suspender la restitución, alegando que la cosa prestada no pertenece al comodante; salvo que haya sido perdida, hurtada o robada a su dueño, o que se embargue judicialmente en manos del comodatario. [Inc. $2^{\circ}$ ] Si se ha prestado una cosa perdida, hurtada o robada, el comodatario que lo sabe y no lo denuncia al dueño, dándole un plazo razonable para reclamarla, se hará responsable de los perjuicios que de la restitución se sigan al dueño. [Inc. $3^{\circ}$ ] Y si el dueño no la reclamare oportunamente, podrá hacerse la restitución al comodante. [Inc. $4^{\circ}$ ] El dueño por su parte tampoco podrá exigir la restitución sin el consentimiento del comodante, o sin decreto de juez". Cabe indagar si el segundo segmento del artículo 2183 del $C C$. es aplicable a la prenda sin desplazamiento, de modo que su pignoratario se vea afectado por las prescripciones del artículo 2183. La respuesta es negativa. El citado artículo concibe sus reglas para un contrato real, que obliga al actual tenedor a restituir la cosa recibida a quien se le entregó, lo que vale para el comodato, con respecto al cual se formula el artículo, el depósito (véase el artículo 2233 del CC.) y la prenda con desplazamiento (artículo 2390). Ahora bien, el pignoratario en la prenda sin desplazamiento, por este mismo hecho nada tiene que restituir; así que no le son aplicables las reglas del artículo 2183 del $C C$.

${ }^{50}$ GuZmán BRito (n. 45), pp. 61-153; Él mismo, "La prenda sin desplazamiento de cosas corporales e incorporales futuras", en Revista de Derecho de la Pontificia Universidad Católica 
a) En lo que atañe a la cosa pignorable, el artículo 1 dispone: "El contrato de prenda sin desplazamiento tiene por objeto constituir una garantía sobre una o varias cosas corporales o incorporales muebles [...]"; y el artículo 5 repite y completa: "Podrá constituirse prenda sobre todo tipo de cosas corporales o incorporales muebles, presentes o futuras [...]". Así que, a fin de cuentas, el objeto pignorable consiste en cosas corporales o incorporales muebles, bien presentes, bien futuras ${ }^{51}$. Los artículos 6 a 12 y 14, desarrollan este principio general y lo aplican a algunos objetos tipificados: ciertos derechos reales administrativos de concesión pública, los créditos nominativos, los valores emitidos sin impresión física del título, bienes o derechos futuros, cosas importadas que aun no han llegado al país, grupos de bienes de una misma clase o universalidades de hecho, inmuebles por destinación o adherencia.

Las cosas corporales pignorables pueden ser singulares, aunque sean muchas, y en tal caso la convención debe mencionar su "individualización o caracterización" (artículo $3 \mathrm{~N}^{\circ} 3$ ); o bien consistir en un grupo de bienes de la misma clase o universalidades de hecho (artículo 11); o en flujos de dinero (artículo $6 \mathrm{~N}^{\text {os }} 1,2,4,5$ y 6 ); y ahora, aunque igualmente deba individualizarse y caracterizarse el conjunto o el flujo, no es necesario hacer lo propio con sus componentes, que por lo general consisten en fungibles.

Bajo el concepto de cosas incorporales se mientan los derechos reales y personales o créditos (artículo 576 del $C C$.), que sean muebles según el artículo 580 del $C C$., bien porque el derecho real se ejerza sobre una cosa corporal mueble, bien porque el personal consista en la deuda de una cosa así. De hecho, entre los reales son susceptibles de prenda sólo el usufructo de muebles, el de aprovechamiento de aguas muebles y los derechos administrativos de concesiones señalados en el artículo 6, en cuanto también recaen sobre muebles.

b) En lo referente al segundo objeto de la prenda, el artículo 1 ofrece una primera aproximación: "El contrato de prenda sin desplazamiento tiene por objeto constituir una garantía [...] para caucionar obligaciones propias o de terceros"; pero es más definitivo el artículo 4: "Podrán caucionarse con esta prenda cualquier clase de obligaciones, presentes o futuras, estén o no

de Valparaíso, $\mathrm{N}^{\mathrm{o}}$ 31, Valparaíso, $2^{\circ}$ semestre de 2008, pp. 221-254; Fabián ElorRiagA De Bonis, "La prenda de créditos nominativos en la nueva normativa de la prenda sin desplazamiento", en Carlos Pizarro Wilson (coordinador), Estudios de Derecho civil.Jornadas Nacionales de Derecho Civil, Olmué, 2008, Santiago, LegalPublishing, 2009, IV, pp. 549-561. Véase la nota siguiente.

${ }^{51}$ Los muebles inmovilizados por su adherencia o destinación a un inmueble son actualmente pignorables como muebles futuros, para cuando sean separadas o desafectadas (artículo 14). Sobre esto, véase: Alejandro GuZMÁn BRITO, "La prenda sin desplazamiento de inmuebles por adherencia o destinación y su concurrencia con otras prendas o con una hipoteca", en Homenaje al profesor Pablo Rodríguez Greza la fecha de esta publicación en prensa. 
determinadas a la fecha del contrato". Por consiguiente, pueden caucionarse con esta convención toda clase de obligaciones, bien propias o ajenas, bien presentes o futuras, bien determinadas o no determinadas.

Todavía puede especificarse la idea expresada con el giro "cualquier clase de obligaciones", que él abraza las obligaciones de dar, hacer o no hacer, civiles o naturales, condicionales, a plazo o modales, alternativas y facultativas, de género o especie, mancomunadas o solidarias, divisibles o indivisibles, con o sin cláusula penal (para garantizar la obligación principal o la del pago de la pena o ambas), de medio o de resultado, etcétera., emanen de la fuente de que emanen, vale decir, bien de la ley, bien de un contrato o cuasicontrato, bien de un delito o cuasidelito.

c) En lo relativo al objeto obligacional de la prenda, la ley permite la doble modalidad de que ésta pueda caucionar una o muchas obligaciones determinadas; o bien un género de ellas bajo el concepto de garantía general. El artículo 3 dispone:

"El contrato de prenda deberá contener, a lo menos, las siguientes menciones:/ [...]/ 2) La indicación de las obligaciones caucionadas o bien de que se trata de una garantía general. En caso que sólo se refieran los documentos donde constan las obligaciones garantizadas y éstos no estuvieren incorporados en un registro público, deberán ser protocolizados en copia simple al momento de la celebración del contrato de prenda [....".

Esta norma ya ha sido estudiada ${ }^{52}$ y a lo dicho nos remitimos.

\section{Causa}

a) Para no ingresar en la compleja y difícil materia de la causa de los actos, contratos y convenciones, que nos llevaría lejos, nos limitaremos a aplicar el concepto que de la causa ofrece el inciso 2 del artículo 1467 del $C C$., como "el motivo que induce al acto o contrato". Desde esa perspectiva, el motivo que induce a la celebración de la convención prendaria no puede ser otro que el acto o hecho cuyos efectos se desea garantizar. Si lo hay, la prenda tiene causa; si no lo hay, carece de tal; si es declarado nulo o se extinguen él o sus efectos, su causa cesa; si el acto o hecho causales son ilícitos, por ser contrarios a la ley, a las buenas costumbres o al orden público (artículo 1467 inciso $3^{\circ}$ del $C$ C.), la causa de la prenda es ilícita. Lo anterior significa que la causalidad de la prenda y su accesoriedad son dos modos de estudiar la misma cuestión.

${ }^{52}$ Véase, más arriba, el cap. vII, 3. 
b) Aun es necesario discutir otro aspecto que asume aparente causalidad en la convención prendaria, cuando ésta es celebrada para garantizar obligaciones de terceros, vale decir, ajenas al pignorante. En tal caso, la causa de la convención es la misma antes descrita; pero la convención prendaria se ve envuelta en una relación que es necesario examinar.

El pertinente análisis comienza por indagar la operación que explica por qué alguien celebra una convención prendaria en garantía de obligaciones ajenas. En tal caso, la respuesta puede ser:

i) porque el deudor le encomendó la constitución de una prenda en su beneficio, y se trata de un mandato entre el deudor, como mandante, y el tercero-pignorante, como mandatario;

ii) por que éste asumió espontáneamente caucionar con prenda la obligación de un tercero, y se trata de una gestión de negocio ajeno, que se traba entre el pignorante, como agente oficioso, y el deudor, como interesado en el negocio gestionado;

iii) porque el tercero-pignorante quiere donar condicionalmente al deudor caucionado, constituyendo prenda por alguna obligación suya con renuncia a la acción de reembolso del importe perdido por él si llega el caso de tener que pagar la obligación caucionada para liberar la prenda o tener que sufrir su realización; caso en el cual la donación queda formada entre el pignorante, como donante, y el deudor, como donatario;

iv) porque el tercero-pignorante quiere acreditar condicionalmente al deudor caucionado, constituyendo prenda por alguna obligación suya con pacto de aplazar el ejercicio de la acción de reembolso del importe perdido en los mismos eventos precedentemente indicados, a un término posterior al pago o a la realización; caso en el cual la relación crediticia queda formada entre el pignorante, como acreedor, y el deudor de la obligación caucionada por aquél, como deudor suyo del dicho importe;

v) porque el tercero-pignorante quiere satisfacer lo que debe al deudor por quien cauciona, pagando en su momento la deuda caucionada para liberar la prenda o sufriendo su realización, de modo que el importa de lo pagado o el valor perdido de la prenda ejecutada se imputen a la dicha deuda, que entonces queda extinguida como por pago.

En todos estos casos, el pignoratario es completamente ajeno a la operación explicativa de que el pignorante celebre una convención prendaria con él, dirigida a caucionar cierta obligación, no propia, sino de un tercero, deudor del pignoratario; el cual hasta puede ignorar la existencia de tal operación. Por consiguiente, ni el pignorante ni el deudor caucionado por él pueden oponer, a modo de acción ni excepción, nada emanado de esa 
operación al pignoratario. Lo contrario es entre el pignorante y el deudor caucionado, partícipes de la operación, que entonces se la pueden oponer entre sí. Por consiguiente, cabe decir que las cinco operaciones antes descritas, aunque explican la prenda, la explican entre el pignorante y el deudor caucionado por aquél y no con respecto al pignoratario; así que no puede decirse que sean causa de la prenda, atendida la incongruencia de partes que se da entre los intervinientes en tales operaciones y los intervinientes en la convención prendaria misma.

\section{EFECTOS DE LA CONVENCIÓN PRENDARIA}

a) El primer efecto esencial de la convención prendaria es hacer posible la constitución del derecho real de prenda sin desplazamiento, merced a la inscripción de la misma en el Registro de Prendas sin Desplazamiento (artículos 24 y 25). El pignorante no está obligado él mismo a hacer tal inscripción ni ella es inmediata carga del pignoratario. Como ya quedó advertido, operar la inscripción es un deber de oficio cooperativo del notario ante quien se otorgó la escritura pública de la convención o que autorizó las firmas del instrumento privado que lo contiene y del Servicio 206 del Registro Civil e Identificación, a cuyo cargo está la administración del aludido Registro. Al primero compete el deber de remitir al segundo una copia autorizada de la convención de prenda, de su modificación o su alzamiento (resciliación) y una copia de los documentos en que consten las obligaciones garantizadas que se hubieren protocolizado en su registro, si éstas no estuvieren indicadas precisamente en la convención de prenda, dentro del plazo de tres días hábiles, exceptuados los días sábado, contado desde la fecha de suscripción de la escritura pública en que consta la convención o, tratándose de instrumentos privados, desde su fecha de protocolización (artículo 24 inciso $1^{\circ}$ ). Al segundo compete el deber de ejecutar la inscripción (artículo 28 inciso $3^{\mathrm{O}}$ ). Sólo si el notario omite cumplir su oficio de remitir copia de la convención al Servicio del Registro Civil e Identificación, el interesado, vale decir, el pignoratario, podrá concurrir directamente a éste y obtener la inscripción (artículo 24 inciso 3 último segmento); lo cual no es, por cierto, una obligación suya, sino tan sólo, como quedó anticipado, una carga.

b) El segundo efecto esencial de la convención prendaria es hacer responsable al pignorante por la culpa grave en la conservación de la cosa pignorada (artículo 18), desde que aquélla quede perfecta. Se observará, pues, que tal responsabilidad no empieza con la inscripción de la convención, que dé origen al derecho real, mas con la convención misma. Si, en consecuencia, las cosas empeñadas perecen o se deterioran por culpa grave 
del pignorante antes que la convención haya sido inscrita, de todos modos aquél responde al pignoratario.

Conviene mucho tener presente que esta responsabilidad desaparece en el caso de la pignoración de conjuntos de cosas o universalidades de hecho, cuando las partes se abstuvieron de pactar que el pignorante no pudiere utilizar, reemplazar, transformar o enajenar sus componentes (artículos 11 inciso 1 y 18 inciso $1^{\circ}$, segmento final). Esta última norma, en efecto, descarga de responsabilidad al pignorante si éste haya procedido "legítimamente" conforme con el artículo 11. En lo civil, eso significa que no haya transgredido a algún acuerdo prendario, como aquéllos permitidos por los artículos 11 inciso $1^{\circ}$ parte final, en orden a no utilizar, reemplazar, transformar o enajenar absolutamente; 17, en orden a no enajenar o gravar; o 19, en orden a una utilización especificada en la convención.

c) Supuesta la convención prendaria, si le fueron añadidos todos o algunos de los convenios tipificados por la ley -que estudiaremos con detalle más adelante ${ }^{53}$ - o cualesquier otros no tipificados que las partes conciban, con la perfección de la dicha convención esos convenios empiezan a producir su efecto de inmediato, en cuanto sea posible o aplicable, sin necesidad de esperar la inscripción de la convención. Ya hemos advertido que las sujeciones impuestas por tales convenios al pignoratario no pueden atribuirse a la convención prendaria misma; pero es evidente que no pueden producir su efecto sin ella. La convención a su respecto es, pues, condición o presupuesto, no fuente.

Por otra parte, tales sujeciones -como también fue adelantado- no son prestaciones obligacionales, sino cargas del pignorante: cuando éste transgreda los convenios de que tratamos, el acreedor no puede exigir su cumplimiento o pedir indemnización de perjuicios, sino sólo acelerar la deuda y realizar la prenda. Únicamente en el caso en que la transgresión hubiera importado una disminución o la extinción de la garantía, como fuere el caso en que, habiéndose pactado en la convención que la cosa empeñada no fuese usada más que de una manera especificada (segmento segundo del artículo 19), y el pignorante la utilizara con culpa grave de otra que la destruye o deteriora severamente, puesto que entonces no podrá haber realización o el precio de venta que se obtenga será inferior al que se obtendría de haber permanecido sana la cosa, el acreedor queda en condiciones de demandar la indemnización de la diferencia y sólo de ésta $^{54}$. Nada de lo cual está dicho en la ley; pero se deduce de las reglas generales sobre incumplimiento de las convenciones.

\footnotetext{
${ }^{53}$ Véase el cap. XI.

${ }^{54}$ Vale decir, no puede demandar el lucro cesante, porque la prenda sana no lo garantizaba; a menos que el lucro cesante derive del proceso posterior a la pérdida o deterioro.
} 
Se tendrá presente que, en estos casos es aplicable a la prenda sin desplazamiento lo dispuesto por el artículo 1496 del $C C$. en el segmento segundo de su $\mathrm{N}^{\circ}$ 2:

"El pago de la obligación no puede exigirse antes de expirar el plazo, si no es: [...]/2. Al deudor cuyas cauciones, por hecho o culpa suya, se han extinguido o han disminuido considerablemente de valor. Pero en este caso el deudor podrá reclamar el beneficio del plazo, renovando o mejorando las cauciones".

Queda, pues, consentido al deudor desacelerar la deuda, esto es, reclamar el beneficio del plazo original, si renueva o mejora la garantía disuelta o menoscabada ${ }^{55}$.

d) Algunos de los delitos prendarios previstos en el título $7^{\circ}$ de la ley, pueden cometerse inmediatamente de perfeccionada la convención prendaria, esto es, aun antes de inscribirse; con mayor razón después.

El artículo 39 dice:

"Serán castigados con las penas señaladas en el artículo 473 del Código Penal:/ 1) El que defraudare a otro disponiendo de las cosas constituidas en prenda en conformidad a esta ley, sin señalar el gravamen que las afecta o constituyendo prenda sobre bienes ajenos como propios [...];/2) El deudor prendario y el que tenga en su poder la cosa constituida en prenda en conformidad a esta ley que, defraudando al acreedor prendario, la altere, oculte, sustituya, traslade o disponga de ella, y/ 3) El deudor prendario que, tratándose de prendas de créditos o de cualquier otra clase de derechos constituidos en prenda en conformidad a esta ley, defraude al acreedor prendario, ocasionando la pérdida o el menoscabo de los derechos otorgados en garantía”.

En este momento interesa destacar la ya enunciada proposición, en orden a que la posibilidad de comisión de estos delitos empieza con la perfección de la convención. En el $\mathrm{N}^{\mathrm{O}} 1$ se dice: "las cosas constituidas en prenda" y "constituyendo prenda sobre bienes ajenos" -la primera expresión se repite en el $\mathrm{N}^{\mathrm{O}} 3$ con respecto a los derechos-, y las cosas y derechos se constituyen en prenda precisamente en la convención, como dice su definición del artículo 1. El deudor prendario, a que se refiere $\operatorname{los} \mathrm{N}^{\text {os }} 2 \mathrm{y}$ 3 , lo es merced a la convención, no a la constitución del derecho real.

${ }^{55}$ Véase un caso en que lo señalado en esta norma no es posible, más adelante, en el cap. XI, 10, d). 
Por lo demás, es del todo correcto que se proteja al pignoratario y a terceros contra las defraudaciones provenientes del pignorante, ya desde la convención sin esperar a la constitución del derecho real, porque aquéllas pueden ser cometidas desde entonces. El pignorante, antes de inscribirse la convención, podría, por ejemplo, ocultar o destruir lo que empeño en aquélla. ¿Por qué la ley hubiera de haber dejado impune semejante conducta?

\section{EXTINCIÓN DE LA CONVENCIÓN PRENDARIA}

1. En esta materia debemos distinguir entre la extinción de la convención prendaria, la de las obligaciones que accidentalmente pueden acceder a aquélla y la del derecho real de prenda. Ahora sólo nos interesa la extinción de la convención sola y como tal, que opera en estado puro o aisladamente cuando el derecho real aún no ha sido constituido. Tal acaece por:

i) el mutuo disenso o resciliación, que la ley denomina "alzamiento" y debe someterse a las mismas formalidades prescritas para la convención, a saber, o escritura publica o instrumento privado, caso en el cual las firmas de sus otorgantes deben ser autorizadas por un notario y el instrumento debe ser protocolizado en el registro del mismo notario que autorizó las firmas (artículo 2);

ii) la confusión de las calidades de pignorante y pignoratario en una misma persona (artículo 2406 inciso $2^{\circ} \operatorname{del} C C$.);

iii) el evento de la condición resolutoria expresa que haya podido someterse la convención prendaria (artículo $1567 \mathrm{~N}^{\mathrm{o}} 9$ y título $4^{\mathrm{O}}$ del libro IV del $C C$., en lo aplicable $)^{56}$;

iv) el cumplimiento del plazo resolutorio que las partes hayan acordado para la eficacia de la prenda;

v) pasar el dominio de la cosa empeñada al pignoratario (artículo 2406 inciso $2^{\circ}$ del $C C$.);

vi)perder su dominio sobre la cosa empeñada el pignorante, merced al cumplimiento de la condición resolutoria que lo afectaba (artículo 2406 inciso $3^{\mathrm{O}}$ );

vii) cesión de un crédito garantizado con prenda especial sin desplazamiento, cuando en el Registro de Prendas sin Desplazamiento no consten el crédito garantizado ni de la posibilidad de cesión de la prenda (artículo 38);

viii)la novación del crédito garantizado, sin reserva de su prenda como caución de la nueva obligación (artículo 1642 del $C$ C.);

\footnotetext{
${ }^{56}$ Ya que nada impide que sus partes le inserten tal condición.
} 
x) la destrucción completa de la cosa pignorada por caso fortuito o fuerza mayor (título $19^{\circ}$ del libro Iv del $C C$.);

x) la renuncia a inscribir la convención prendaria formulada por el pignoratario (que equivale a la remisión de la prenda) y

xi) la nulidad de la convención.

Por cierto, puede acaecer que estas causas de extinción operen también como tales con respecto a las obligaciones prendarias accidentales, cuando existan merced a acuerdos anexos a la convención misma, y al derecho real, desde que quede constituido; pero eso pertenece a otro estudio.

2. Cabe indagar si la prescripción afecta a la convención prendaria perfecta, pero aún no inscrita, de modo que el transcurso del tiempo fijado para aquélla impida la inscripción. Ya quedó recordado que ejecutar la inscripción es un deber de oficio que afecta al notario ante quien se otorgó la escritura pública o el instrumento privado cuyas firmas autorizó y luego protocolizó y al Servicio del Registro Civil e Identificación (artículo 24). Proceder a la inscripción no es, pues, una prestación del pignorante, por cuya omisión pueda ser demandado; así que no cabe pensar en una eventual excepción de prescripción suya contra el pignorante.

Si el notario o el Servicio del Registro Civil e Identificación no cumplen con su deber, el pignorante puede exigir la inscripción a dicho Servicio 210 (artículo 24 segmento final). Y en cualquier caso en que la inscripción sea denegada por el Servicio, el perjudicado con la negativa, que normalmente es el propio pignoratario, tiene expedita una acción ante la justicia ordinaria para solicitarle que ordene al Servicio ejecutar la inscripción denegada (artículo 28 inciso $4^{\circ}$ ). Ahora bien, puede ocurrir que el pignoratario omita ejercer durante el plazo de prescripción sus recursos dirigidos a obtener la inscripción; y se pregunta si en tal caso podría el pignoratario alegar la prescripción al menos por vía de acción entablada para que se declare aquélla. La respuesta es negativa, porque en el Derecho Privado chileno no existe la prescripción derivada del no ejercicio de una carga, que no constituye propiamente cierta obligación exigible. El pignorante no tiene ninguna obligación -a lo más un interés, de donde la carga- de hacer inscribir; en consecuencia, no se le podría oponer una prescripción cuando instara por aquélla.

\section{Xi. Convenios opcionales}

EN LA CONVENCIÓN PRENDARIA

En la convención prendaria, sus partes pueden adoptar los convenios de objeto posible, determinado y lícito que quieran, en ejercicio de la general libertad contractual que acuerdan las leyes civiles. Pero la ley de prenda 
sin desplazamiento ha tipificado ciertos convenios para la convención de prenda sin desplazamiento, aunque no como necesarios o forzosos, sino como voluntarios.

\section{Convenio de limitación de la garantía prendaria}

El artículo $3 \mathrm{~N}^{\mathrm{o}} 4$ describe una de las menciones que la convención prendaria "deberá contener" con las siguientes palabras: "La suma determinada o determinable a la que se limitare la prenda o la proporción en que debiere caucionar diversas obligaciones, si fuere el caso".

a) El tenor literal de la norma hace creer, aunque levemente, que su sentido es que las partes deban mencionar, bien una suma determinada o determinable a la que se limitare la prenda, bien una proporción en que la prenda deba caucionar diversas obligaciones, según fuere el caso; de modo de estar forzadas a escoger.

Que tal no es un dilema ofrecido por la disposición -el cual fuere muy anómalo, porque obligaría a limitar la prenda en todo caso- lo muestra la historia de su formación textual.

En el "Mensaje" del Ejecutivo, el tenor literal de la norma prevista como artículo $3 \mathrm{~N}^{\circ} 4$ era el siguiente: "El contrato de prenda debe contener, a lo menos, las siguientes menciones:/ [...] 4) La suma determinada a la que se extiende la prenda en el caso de haberse limitado a una cantidad" ${ }^{57}$. Resulta claro aquí que el mandato de mencionar la suma determinada a la que se extiende la prenda sólo rige en el caso de haberse limitado a una cantidad la garantía de la prenda acordada en él; y va de suyo que si las partes no acordaron limitarla a cierta suma, nada tienen que mencionar; ni siquiera el hecho de haber expresamente acordado la ilimitación; así que no se trata de un mandato absoluto, sino condicionado o hipotético. De acuerdo con esto, el proyecto concedía la facultad de limitar la garantía prendaria a una suma determinada, mas, por cierto, no obligaba a limitarla; y dejaba abierta la posibilidad de que las partes guardaran silencio al respecto, caso en el cual tendría que producirse el efecto, por lo demás normal, de una prenda con garantía a toda la deuda.

La Comisión de Hacienda de la Cámara de Diputados modificó el texto original de la disposición, que devino en el siguiente artículo $3 \mathrm{~N}^{\mathrm{o}}$ : "El contrato de prenda debe contener, a lo menos, las siguientes menciones:/ [... 4) La suma determinada o determinable a la que se limitare la prenda,

57 "Mensaje presidencial", en Historia de la ley $N^{0}$ 20.190. Biblioteca del Congreso Nacional, 5 de junio de 2007, en: http://www.bcn.cl/histley/lfs/hdl-20190/HL20190.pdf, pp. 69-70. 
si fuera el caso" 58 . La expresión "si fuera el caso" reemplazó a la anterior: "en el caso de haberse limitado a una cantidad"; pero con su mismo sentido, aun cuando el condicional queda, incluso, reforzado por el empleo de la preposición 'si'. Su sentido es, pues, que debe mencionarse la suma sólo si es el caso de haberse acordado la limitación.

El texto finalmente promulgado del $\mathrm{N}^{\circ} 4$ hubo de ser definido en la Comisión de Hacienda del Senado, que lo redactó de esta manera: "El contrato de prenda debe contener, a lo menos, las siguientes menciones:/ [...]) 4) La suma determinada o determinable a la que se limitare la prenda o la proporción en que debiere caucionar diversas obligaciones, si fuere el caso" 59 . En esa comisión, a la posibilidad de limitar la prenda a una suma determinada o determinable, se añadió la de limitarla según una "proporción". La expresión "si fuere el caso" (como se ve, se varió la forma verbal), que venía como se vio, desde antes, y que entonces regía en función condicional una única posibilidad, ahora rige dos, en la misma función; así que la norma quiere decir que si es el caso que las partes acordaran limitar la prenda según una suma determinada o determinable, o si es el caso que acordaron limitarla según una proporción, deben mencionarlo. Para un tercer caso, que es el que las partes no hayan acordado limitar de ninguna manera la prenda, no se exige mención alguna. Porque, de hecho, en esta 212 materia las alternativas supremas son limitar la prenda o no limitarla. Pero fijar una suma determinada o determinable o fijar una proporción en función limitadora de la prenda son, en cambio, subalternativas del primer extremo de la alternativa suprema. Ahora bien, esta última no está regulada en la ley, que sólo trata de la subalternativa. Así que resulta ser claro, como ya desde el principio, que las partes son libres para limitar o no limitar la prenda y que no están obligadas a pronunciarse sobre el punto, porque su silencio implica que la prenda actúa normalmente, como garantía ilimitada con respecto a toda la deuda. Sólo si acuerdan limitarla deben señalar el modo de la limitación, a saber, por fijación de una suma determinada o determinable o por indicación de una proporción. Por consiguiente, este tema pertenece al de los pactos opcionales de la convención prendaria; y el contenido del $\mathrm{N}^{\mathrm{o}} 4$ del artículo 3, que señala lo que la convención debe contener, está mal localizado ahí.

b) En principio, la prenda sin desplazamiento garantiza el monto de la deuda, que comprende el capital y sus intereses, y de los gastos y costas de la realización (artículo 15, cfr. artículo 2402 del $C C$.); y en tales rubros aquélla

58 "Primer informe de la Comisión de Hacienda de la Cámara de Diputado", en Historia de la ley $N^{0}$ 20.190. Biblioteca del Congreso Nacional, 5 de junio de 2007, en: http://www. bcn.cl/histley/lfs/hdl-20190/HL20190.pdf, p. 775.

${ }^{59}$ Op. cit., p. 1.029. 
encuentra su limitación natural por así llamarla: garantiza todo el monto dicho, pero nada sobre él, porque cualquier exceso para el cual se concediera prenda, que sería no debido, haría que ésta dejara de ser accesoria ${ }^{60}$.

La misma limitación encuentra la garantía hipotecaria (artículos 2424 y 2402 del $C$ C.). Pero en ésta, el artículo 2431 inciso $1^{\circ}$ del $C C$. abrió la posibilidad de que su garantía quede limitada a cierta suma determinada: "La hipoteca podrá limitarse a una determinada suma [...]". La ley $\mathrm{N}^{\mathrm{o}} 20.190$, como se ve, extendió tal posibilidad a la prenda, con respecto a la cual, cuando es con desplazamiento, no está considerada en el Código Civil; y la amplió al caso de una suma "determinable" ${ }^{61}$. Igual que en la hipoteca, en la cual, por cierto, no existe ningún deber sino una mera facultad de limitar la garantía ("podrá limitarse"), la disposición del artículo 3 No 4 supone implícitamente -como ya ha quedado suficientemente demostrado- una libertad de las partes para limitar o no limitar la garantía prendaria. En consecuencia, no necesitan decir nada al respecto; sólo que si guardan silencio, entonces la prenda contraída garantiza el "total del monto del crédito, incluidos los intereses, gastos y costas, si los hubiere", como expresa el artículo 15; lo cual corresponde a la extensión normal y natural de la garantía prendaria, ya según el artículo 2402 del $C C^{6}{ }^{62}$.

c) Así que la ley admite convenir una "limitación" a la garantía prendaria, que entonces podemos denominar convencional; y consiste en la subalternativa de fijar

i) una suma determinada o determinable o, bien,

ii) una proporción en que la prenda deba caucionar diversas obligaciones. La finalidad de la limitación es que la garantía prendaria cubra algo menos que lo finalmente debido ${ }^{63}$.

${ }^{60} \mathrm{El}$ punto no tiene nada que ver con la prenda en garantía general ni de deudas de monto indeterminado, para las cuales sigue siendo cierto que la garantía sólo cubre lo debido y ningún exceso indebido.

${ }^{61}$ Aunque no debe quedar excluido que la voluntad de las partes pueda limitar la garantía hipotecaria también a una suma determinable. Al revés, el artículo 2431 del $C C$. no conoce la limitación de la garantía hipotecaria según cuotas de la obligación garantizada. Pero, en realidad, nada impide que sus partes establezcan semejante modo de limitación a la hipoteca.

${ }^{62}$ Esta disposición dice que del precio de venta de la prenda se deben pagar los "costos"; el artículo 15 dice, en cambio, que los "gastos y costas". Con la última expresión alude a las costas procesales y personales; con la primera, a las demás expensas de la realización (por ejemplo, los honorarios del martillero). Así que la genérica expresión 'costos' del Código Civil cubre las más específicas de "gastos y costas" de la ley.

${ }^{63}$ Por ello es limitación. Sin embargo, la limitación, mirada en términos cuantitativos o numéricos, inicialmente puede aparecer como superior al monto del capital de la obligación, como si se dice que la garantía queda limitada a 1.500 en circunstancias que la deuda es de 1.000. Por cierto, si en el momento de la realización la deuda permanece en ese monto, sólo éste es el que puede exigir como pago el acreedor. En eventos como ése, la limitación 
Ello significa que cualquiera haya sido el precio de la cosa pignorada obtenido en la subasta por sobre la suma determinada o determinable o por sobre la suma que equivalga a la cuota de la obligación, fijadas como límite, hay que liquidar el interés del acreedor lo mismo que si se hubiera vendido precisamente en esa suma determinada o determinable o en una suma igual a la proporción, establecidas como límite, sobre las cuales sumas, pues, se aplica lo dispuesto por el artículo 15 de la ley. En consecuencia, el excedente del precio de venta por sobre la limitación, cualquiera que sea el modo en que se la estableció, debe ser entregado al pignorante.

La limitación y sus modos de fijarse son igualmente aplicables a la prenda en función de garantía especial, sea una, sean varias las obligaciones caucionadas; y a la prenda en función de garantía general. Cuando hay varias obligaciones caucionadas, esos modos pueden combinarse, de guisa que, con respecto a una obligación, la limitación consista en una suma determinada o determinable; y con respecto a otra, en una cuota de sí misma.

d) El tenor literal del segundo segmento del $\mathrm{N}^{\mathrm{o}} 4$ del artículo 3 es ambiguo: "proporción en que [la prenda] debiere caucionar diversas obligaciones". Es ambiguo, pero no oscuro o ininteligible. Envuelve dos posibilidades:

i) la fijación de una proporción a partir de la obligación caucionada y significa limitación a una cuota de ella (limitación pro parte crediti); y

ii) la fijación de una proporción a partir de la cosa pignorada, y ahora significa limitación a una cuota de ésta (limitación pro parte rei).

Sendos ejemplos aclararán estos conceptos. Frente a dos obligaciones caucionadas en la convención prendaria, las partes pueden, por ejemplo, decir que la prenda garantiza la mitad de una de ellas y dos tercios de la otra, y han limitado la prenda pro parte debiti. Lo cual significa que cualquiera sea el monto del precio de venta de la cosa pignorada obtenido en la licitación, el acreedor consigue de él no más que la mitad del monto de una obligación y no más que dos tercios del de la otra. Si ahora suponemos que las partes declaran afectar un tercio de cierto automóvil como garantía de una obligación y un cuarto del mismo automóvil como garantía de la otra, la limitación ahora es pro parte rei; y significa que cualquiera sea el precio de licitación, un tercio del mismo debe destinarse a pagar una obligación y un cuarto a pagar la otra. Las cuotas involucradas en este modo de limitación son, por cierto, pro indiviso, y no pro diviso (la mitad física de la derecha o de la izquierda del automóvil o, bien, anterior o posterior).

a una suma superior al capital contiene una cautela frente a los crecimientos normales que suelen sufrir las deudas por los intereses y también frente a los costos de la ejecución, ya que los montos de estos dos últimos rubros no pueden conocerse de antemano; así que la limitación ha de operar al final, cuando el capital, los intereses y los costos determinados en la ejecución excedan los 1.500 a que, en el ejemplo, se limitó la hipoteca. 
Hay empero una diferencia entre fijar un monto determinado o una cuota de la obligación o de la cosa como límite. En el primer caso, la limitación comprende el capital, lo intereses, los gastos y las costas, el pago por todos los cuales rubros no puede exceder el monto determinado. En el segundo, en cambio, la cuota limitativa cubre la suma del capital, los intereses, los gastos y las costas, y la parte del precio resultante de aplicarle la cuota definida es la que limita en concreto el pago. Ambos procedimientos pueden conducir a resultados diferentes. Supóngase que la garantía de una prenda de cierta obligación de mil es limitada a quinientos; y que el capital, los intereses, los gastos y las costas montan a mil doscientos. Este modo de limitación implica que sólo quinientos deben destinarse a todos esos rubros. Supóngase ahora que la limitación queda establecida en la mitad de la misma deuda; caso en el cual hay que destinar seiscientos del precio al pago del capital, los intereses, los gastos y las costas, porque tal suma es la mitad de la deuda, que asciende a mil doscientos. En una hipótesis, por ende, el acreedor percibe menos que en el otro.

Nada impide que las partes varíen los efectos antes explicados de cada modo de limitación. Es decir, podrían ellas fijar una suma determinada o determinable como limitación, con expresión de que ella sólo se aplica, por ejemplo, al capital, o a los intereses o a los costos. En tales casos, la limitación vale para el rubro expresado, así que los no expresados deben cubrirse totalmente con el excedente del precio por sobre la limitación (si alcanza, por cierto). A la inversa, también pueden fijar una cuota limitativa para determinado rubro y no para otros; y entonces la cuota se aplica al total del rubro expresado, el cual se paga con la suma concreta que tal aplicación arroje; y los restantes rubros se pagan en su totalidad.

e) El artículo 2431 del $C C$., que en su segmento primero reconoce, como vimos, la posibilidad de limitar la garantía que ofrece la hipoteca a una suma determinada, añade, en su segmento segundo: "[...] pero no se extenderá [sc. la hipoteca] en ningún caso a más del duplo del importe conocido o presunto de la obligación principal, aunque así se haya estipulado". La norma contenida en esta frase, cuyo sujeto es "la hipoteca", se aplica, en términos absolutos ("en ningún caso") a ella, sea que se la haya limitado o no $^{64}$; y contiene la que podríamos considerar como una limitación legal de la hipoteca, que esa norma fija en el doble del importe conocido o presunto de la obligación principal. El inciso 2 del artículo 2431 concede un derecho de reducción de la garantía hipotecaria al deudor. Ahora bien, lo que en este momento importa señalar es que la ley de prenda sin desplazamiento, aunque recogió de la hipoteca la posibilidad de una limitación convencio-

${ }^{64}$ Con todo, el alcance de la disposición ha sido objeto de discusión; véasela en: MerY Berisso (n. 34), N $^{\text {s }} 153-157$, pp. 305-312. 
nal para aplicarla a la garantía prendaria, no adoptó la figura contenida en el segmento segundo del inciso $1^{\circ}$ del artículo 2432 del $C C$., en orden a también limitar legalmente la garantía prendaria en la forma ahí establecida o en otra. Como, por otra parte, tampoco existe una limitación semejante en materia de prenda civil ni comercial, es consiguiente que, en materia de prenda sin desplazamiento, limitación legal de su garantía no haya, ni por analogía ni merced a un inexistente Derecho subsidiario sobre el punto.

f) Si ocurriere que la partes acuerden limitar la garantía prendaria sin señalar la modalidad de la limitación, merced a la fijación de una suma o de una proporción, tal incompleta cláusula no vale por falta de objeto, sin que, empero se afecte el resto la convención.

\section{Convenio de no repignoración}

En principio, la cosa entregada en prenda civil o mercantil no puede ser repignorada a otro, porque no es posible entregarla al nuevo pignoratario destinado; a lo más podría pensarse en aplicar analógicamente el esquema previsto por el artículo $2404 \mathrm{del} C C$., y sin efecto forzoso para el pignoratario que tiene la prenda; vale decir, cuando los tres interesados están de acuerdo. Pero en la prenda sin desplazamiento (lo mismo que 216 en la hipoteca) dogmáticamente no existe el mismo impedimento para imponer nuevas prendas a la cosa que ya una vez fue empeñada. El pignorante, en efecto, podría tener interés en constituir una nueva prenda de aquella clase sobre el bien antes pignorado a alguien; o darlo en prenda con desplazamiento si es ello posible atendida la naturaleza del objeto. En principio esta posibilidad es indiferente para el primer pignoratario, quien mantiene incólume su derecho real de persecución y su preferencia frente a terceros. Por consiguiente, la ley deja amplio margen a que las partes decidan sobre esta posibilidad, a diferencia de la opción adoptada en otras leyes prendarias en que ha prohibido la repignoración sin consentimiento del acreedor ${ }^{65}$.

Frente al punto, las partes pueden asumir las siguientes actitudes en la convención:

a) Guardar silencio sobre la materia; y en tal caso rige el artículo 16, que expresa: "Se podrá constituir una o más prendas sobre un mismo bien [...]". Así que, en efecto, el pignorante puede imponer cuantas sucesivas prendas sin desplazamiento quiera a la cosa precedentemente pignorada. Pero se observará que la norma, en realidad, no distingue clases de prendas;

${ }^{65}$ Véanse los artículos 17 de la ley No 4.097 , sobre prenda agraria, 10 de la ley $\mathrm{N}^{\mathrm{o}} 4.702$ sobre compraventa de cosas muebles a plazo con prenda de las mismas y 18 de la ley $\mathrm{N}^{\circ}$ 18.112 sobre prenda sin desplazamiento. 
así que la repignoración autorizada atañe a todas las posibles. Cuando la ley entre en vigor, cualquier cosa ya pignorada sin desplazamiento podrá admitir sucesivamente la civil y la mercantil con desplazamiento; y, según el tipo de cosa, otras especiales, como la de mercaderías depositadas en almacenes generales de depósito.

Por cierto, ello implicará conflictos de prelación entre las prendas sucesivamente constituidas $\mathrm{El}$ artículo 15 confiere la preferencia del artículo 2474 del $C C$. (y debe entenderse que la remisión es al $\mathrm{N}^{0} 3$ de ese artículo) a la prenda sin desplazamiento:

"El acreedor prendario tendrá derecho a pagarse, con la preferencia establecida en el artículo 2474 del Código Civil, del total del monto del crédito, incluidos los intereses, gastos y costas, si los hubiere. Este privilegio se extenderá, además, al valor del seguro sobre la cosa dada en prenda, si lo hubiere, y a cualquier otra indemnización que terceros deban por daños y perjuicios que ella sufriere".

Por su lado, el artículo 16, junto con autorizar, según ya vimos, la constitución de prendas sucesivas sobre un mismo bien, señala una prelación entre ellas, determinada por el orden cronológico de sus inscripciones: “[...] prefiriéndose por el orden cronológico de sus respectivas inscripciones en el Registro de Prendas sin Desplazamiento".

De acuerdo con ello, si sobre una misma cosa se han constituido sucesivas prendas sin desplazamiento, el orden de prelación entre todas ellas queda determinado por el orden cronológico de las inscripciones de la correspondiente convención en el registro aludido por la norma. Esto no ofrece problemas especiales. Ellos podrían ofrecerse cuando una prenda sin desplazamiento concurra con otra sucesiva posible. Algunas leyes prendarias en actual vigor ofrecen criterios de prelación; pero ninguno la nueva ley, que ha de derogar aquéllas. Supóngase que alguien constituye prenda sin desplazamiento sobre una nave menor (o sea, menor de cincuenta toneladas) a un acreedor; que después la entrega en prenda civil o comercial a otro; y que se hace necesario ejecutar la garantía, cien qué orden se pagan ambos acreedores? Se puede pensar en que el pignoratario sin desplazamiento prefiera a aquél con desplazamiento o viceversa. Sobre el punto, al silencio de la nueva ley se añade que nada pertinente es posible encontrar en los Códigos Civil y de Comercio. Sin embargo, la solución se encuentra en la aplicación del mismo criterio adoptado en el artículo 16: el orden cronológico de la constitución del derecho real; así que, en el caso propuesto, la precedente prenda sin desplazamiento inscrita debe preferir a la posterior prenda con desplazamiento, porque la inscripción constituyó el derecho real de prenda sin desplazamiento antes que la 
entrega constituyera el derecho real de prenda con desplazamiento. Este criterio debe adoptarse en cualquier caso en que no incida ley que señale un criterio de prelación.

De todos modos, este tema más que a la convención prendaria pertenece al derecho real, por lo cual no avanzamos más sobre él aquí.

b) Las partes también pueden acordar expresamente que la cosa pignorada ha de poder ser sujetada a posteriores gravámenes prendarios; y el efecto es el mismo que si hubieran guardado silencio.

c) Asimismo, pueden convenir en que la cosa pignorada no podrá ser sujetada a posteriores gravámenes prendarios. A este caso se refiere el artículo 17:

"Si se ha convenido que las cosas dadas en prenda no pueden gravarse o enajenarse, deberá mencionarse en el registro y su infracción dará derecho al acreedor para exigir la inmediata realización de la prenda, considerándose la obligación caucionada como de plazo vencido. El desposeimiento del adquirente se efectuará conforme al artículo 35, salvo en la situación prevista en el inciso tercero del artículo 25 ".

218 En realidad, como se ve, la norma se refiere a temas más extensos, pues habla de la cláusula de no gravar, lo que incluye, por cierto, a la prenda de cualquier clase, pero también a otros gravámenes no prendarios como un usufructo, y la cláusula de no enajenar ("que las cosas dadas en prenda no pueden gravarse o enajenarse"). Pero limitemos nuestro actual examen sólo a los posteriores gravámenes prendarios.

Si las partes acuerdan que la cosa actualmente pignorada entre ellas no pueda pignorarse en el futuro "deberá mencionarse en el registro" dice la ley, lo cual significa que debe mencionarse en la inscripción que se practica en el registro. Pero, en realidad, hay una imprecisión en esta norma. El convenio de no repignoración debe manifestarse ya en la convención y, por ende, lo que la ley exige es que de él después haya de dejarse constancia en la inscripción, porque no podría acaecer que en esta última se dejara constancia de un convenio que no existe en la convención; y cuando así se hiciera, no se seguiría ninguno de los efectos que señala el artículo 17, porque de hecho no hubo declaración convencional al respecto. En síntesis, el pacto de no repignoración puede ser acordado en la convención, y cuando así haya ocurrido, de él debe dejarse constancia en la inscripción de aquél en el Registro de Prendas sin Desplazamiento.

d) La transgresión de este acuerdo de no repignorar adoptado en la convención y mencionado en el dicho registro tiene una sanción típica: la que suele llamarse aceleración; esto es, la obligación caucionada sujeta a plazo 
empieza a ser de plazo vencido y el deudor queda en mora, así que o paga seguidamente la deuda caucionada o el acreedor puede exigir la inmediata realización de la prenda en la forma ordinaria. Es lo que dice el artículo 17 antes transcrito. Se observará, pues, que la sanción no es ni la nulidad de la repignoración y ni siquiera su inoponibilidad. De lo que se sigue que el Registro Civil no debe negarse a inscribir la prenda posterior apoyado en el argumento de haber un pacto de no repignoración mencionado en la inscripción. Así que, no bien el anterior pignoratario realice la prenda, el posterior puede concurrir a pagarse sobre el precio de venta del objeto empeñado, una vez que el anterior resulte satisfecho en todo lo que tenga facultad de exigir sobre ese precio según el artículo 15; y si no la realiza (lo que está en su potestad hacer) la prenda posterior igual producirá su efecto en el futuro, vale decir, permitir participar en el sobrante del precio después que el precedente pignoratario resulte satisfecho.

e) Antes dijimos que no tiene valor la mención en la inscripción de una convención prendaria en el Registro de Prendas sin Desplazamiento, en orden a no poderse repignorar un objeto ya dado en prenda, si eso no es reflejo de un pacto en tal sentido adoptado en la convención misma. Lo contrario sí es posible, a saber: que las partes hayan pactado la no-repignoración y que de este pacto no se haya dejado constancia en la inscripción, seguramente por error del oficial del Registro Civil, encargado de practicarla (artículo 28 inciso $3^{\circ}$ ). Aunque tal haya sido la causa, lo cierto es que la ley asigna un efecto al hecho de que el pacto de no repignoración establecido en la convención no haya sido mencionado en el registro.

Pero hay alguna dificultad en determinar cuál es ese efecto. Dos son posibles:

i) que el acreedor en cuyo beneficio cedió el pacto no pueda exigir la inmediata realización de la prenda;

ii) que sí pueda, pero que ese pacto no sea oponible al acreedor posterior,

de modo que éste pueda pedir una indemnización de los perjuicios que le ocasionó la realización operada, consistentes en no haber podido satisfacerse por completo sobre la prenda (supuesto que en realidad no haya podido satisfacerse), precisamente debido a la preferencia del anterior pignoratario. Cierto es que este último igual hubiera tenido preferencia en el caso de haberse mencionado el pacto en la inscripción; pero también es cierto que, en tal caso, el segundo, en conocimiento de haber ya prenda, hubiera podido deliberar acerca de si aceptar a su riesgo una caución de grado ulterior, o de exigir otra caución mejor, o de no contratar la obligación principal; y estas tres posibilidades le quedaron vedadas por su desconocimiento del pacto de no repignoración, debido a no habérselo mencionado en la inscripción; de donde el resarcimiento dicho. 
El tenor literal de la norma depone por la primera posibilidad. La norma dice: "Si se ha convenido que las cosas dadas en prenda no pueden gravarse o enajenarse, deberá mencionarse en el registro y su infracción dará derecho al acreedor [...]". Se trata, no de la infracción del convenio sin más, sino de la del "convenio registrado". Por lo demás, como ese convenio favorece e interesa al acreedor y perjudica a los terceros que eventualmente adquieran prendas posteriores a la de aquél, es del todo lógico que la ausencia de su mención en la inscripción pública lo perjudique a él y no a dichos terceros ${ }^{66}$. En otras palabras, la exigencia de mencionarse el pacto en la inscripción es un requisito de su oponibilidad precisamente frente a terceros.

En fin, cabe decir que el hecho de no haberse mencionado el pacto en el registro puede ser rectificado de oficio o a petición de parte interesada ${ }^{67}$.

\section{Convenio de no enajenación o de no imposición de gravámenes no prendarios}

a) El artículo $2404 \mathrm{del} C C$. permite al pignorante:

i) vender la cosa empeñada y

ii) conceder a terceros un título oneroso para el goce o tenencia de la cosa empeñada;

pero supedita la exigencia de ser entregada la cosa por el pignoratario, en cuyo poder está, al comprador o al tercero, a que uno u otro le pague o consigne el importe de la deuda que dicha cosa le garantiza ${ }^{68}$. No vemos razones para limitar la transferencia, con la letra de la ley, al sólo título de venta; así que la analogía permite extender la posibilidad a la enajenación

${ }^{66}$ Añádase que el acreedor puede instar para que se rectifique el error de no haberse mencionado el pacto en la inscripción, como le queda expedito merced al artículo 26 inciso $2^{\circ}$, que se transcribe en la nota siguiente. En este caso, el acreedor es ciertamente el interesado aludido en esa norma.

${ }^{67}$ Artículo 26 inciso $2^{\circ}$ : “[...] de oficio o a requerimiento de cualquier interesado y dentro de un plazo de diez días hábiles, exceptuados los días sábado, a contar de la fecha de la inscripción en el Registro de Prendas sin Desplazamiento, éste podrá rectificar los errores manifiestos en que se pudiere haber incurrido al practicarse la anotación. Con todo, la fecha de la constitución del derecho real de prenda será siempre la de su inscripción original”. En este caso el acreedor es ciertamente el interesado aludido en la norma.

${ }^{68}$ Artículo 2404 del $C C$ : “[Inc. $1^{\circ}$ ] Si el deudor vendiere la cosa empeñada, el comprador tendrá derecho para pedir al acreedor su entrega, pagando y consignando el importe de la deuda por la cual se contrajo expresamente el empeño. [Inc. $2^{\circ}$ ] Se concede igual derecho a la persona a quien el deudor hubiere conferido un título oneroso para el goce o tenencia de la prenda. [Inc. $3^{\circ}$ ] En ninguno de estos casos podrá el primer acreedor excusarse de la restitución, alegando otros créditos, aun con los requisitos enumerados en el artículo 2401". 
por cualquier otro título diferente y aun a la transmisión por legado ${ }^{69}$. No es posible, en cambio, superar la limitación al sólo título oneroso, en el caso del número ii), de modo de tenerse que decir, por injustificado que sea, que el pignorante no puede conferir la cosa empeñada merced a un título gratuito como, por ejemplo, en comodato.

De acuerdo con esto, el pignorante de la cosa empeñada con desplazamiento puede enajenarla, gravarla con derechos reales constituidos a título oneroso que den tenencia, uso o goce a terceros, como un usufructo, y obligarla a título oneroso con derechos personales que también les den tenencia, uso o goce, como en arrendamiento o sociedad.

Estas reglas sufren modificaciones en la prenda sin desplazamiento. $\mathrm{El}$ artículo 17 dice: "Si se ha convenido que las cosas dadas en prenda no pueden gravarse o enajenarse [...]". La norma supone que si nada se ha convenido, la cosa empeñada puede ser objeto de enajenación o gravamen. Las modificaciones, por consiguiente consisten en esto:

i) que ahora se habla de "enajenación" y no sólo de venta; así que no hay necesidad de recurrir a ninguna analogía para admitir que la cosa pignorada sin desplazamiento puede ser transferida a cualquier título gratuito u oneroso y no sólo vendida;

ii) que se habla de "gravar" sin discriminación de si el gravamen es a título gratuito u oneroso.

En el resto, sigue aplicable la tercera posibilidad que concede el artículo 2404 del $C C$., a saber: la de poder obligar la cosa a título oneroso con derechos personales que también den su tenencia, uso o goce, como en arrendamiento o sociedad.

Por consiguiente, el pignorante puede:

i) enajenar a cualquier título la prenda;

ii) gravarla también a cualquier título y

iii) obligarla, como se dijo, a título oneroso con derechos personales que también les den tenencia, uso o goce.

b) Sin embargo, la ley permite que las partes pacten sobre estos particulares. Las posibilidades son tres:

i) Guardar silencio sobre la materia, y en tal caso quedan expeditas las reglas precedentemente resumidas, en orden a poder enajenar, gravar u obligar a título onerosos la prenda el pignorante. Pero es sumamente importante que la ley haya vuelto a modificar al Código

${ }^{69}$ Ningún acto de enajenación de la prenda puede perjudicar al acreedor, atendido su derecho de exigir el pago de la deuda garantizada a aquél a quien deba ir la cosa merced a la enajenación, sea el comprador, sea el donatario, sea el copermutante, sea el acreedor a quien la cosa fue obligada a ser dada, etc.; así que, en efecto, no hay razón para limitar la posibilidad de transferencia al sólo título de venta. 
Civil en cuanto a los efectos del respectivo acto. Como quedó dicho, para ese cuerpo legal el tercero que pretenda la entrega de la cosa por el pignoratario, tiene la carga de pagarle el importe de la deuda. No es tal el caso en la prenda sin desplazamiento, porque, estando la prenda en poder del pignorante, la puede entregar él directamente al tercero a quien la enajenó, gravó u obligó y no está dicho que el tercero tenga la carga de pagar al pignoratario antes de recibirla ni que el pignorante deba pagarle antes de entregarla al tercero. Sin embargo, el acreedor conserva intacto su derecho real de prenda para perseguir la cosa y realizarla.

ii) Las partes podrían acordar expresamente que la cosa pignorada podrá ser enajenada, gravada u obligada a terceros por el pignorante; $\mathrm{y}$, en tal caso, los efectos son los mismos que si hubieran guardado silencio.

iii) En fin, podrían aquéllas pactar que la cosa no sea gravada, enajenada u obligada a terceros por el pignorante. Si tal pacto es mencionado en la inscripción de la convención en el Registro y es infringido por el pignorante, se acelera la deuda a plazo caucionada, que empieza a ser de plazo vencido, de modo que el deudor queda en mora, así que o paga seguidamente esa deuda o el acreedor puede exigir la inmediata realización de la prenda de acuerdo con las reglas generales.

Si el pacto no fue mencionado en la inscripción y el pignorante lo vulnera, no se pueden producir los efectos precedente descritos; y sólo se abre la posibilidad de que el acreedor reclame una indemnización al pignorante, si es que la transgresión del pacto le produjo algún perjuicio; lo que puede ocurrir, como cuando el tercero pierde o deteriora la cosa. Pero en ningún caso no ve menoscabado su derecho real de prenda para perseguir la cosa y realizarla.

c) Conviene recordar que quien dispone de las cosas pignorada sin dar a conocer el gravamen que la afecta al interesado, comete el delito previsto por el artículo 39: "Serán castigados con las penas señaladas en el artículo 473 del Código Penal:/ 1) El que defraudare a otro disponiendo de las cosas constituidas en prenda en conformidad a esta ley, sin señalar el gravamen que las afecta [...]". El delito se comete en cualquier caso, vale decir, sea que haya autorización para disponer, sea que no la haya. Así que, no bien este registrado el pacto de no enajenación, hay delito, supuesto que haya habido defraudación. Esto significa que si el interesado se enteró del pacto examinando el registro en donde consta dicho pacto, defraudación no puede haber, aunque el pignorante no lo haya dado a conocer. 


\section{Convenio de fijación de cierto lugar donde deba mantenerse la cosa empeñada}

a) Por ser de una prenda que estatuye la ley $\mathrm{N}^{0} 20.190$, ella recae sobre muebles, los cuales, por definición, admiten ser transportados de un lugar a otro. La característica con que aquélla fue estatuida, por otro lado, es la del no desplazamiento de la cosa en caución, así que su constituyente conserva la tenencia, el uso y el goce de tal cosa, como dicen los artículos 1 y 18. Por consiguiente, el pignorante puede transportar la cosa pignorada desde y hacia donde quiera. Sin embargo, el pignoratario pudiere tener interés en que ella permaneciere estacionaria o inmovilizada en el interior de cierto lugar conocido, como manera de sustraerla a un eventual ocultamiento que impida la persecución, o para desfungibilizarla si es fungible, atendidas las propiedades en tal sentido que ofrece la localización ${ }^{70}$.

b) Ahora bien, la ley no ha impuesto ella misma el deber de fijar un lugar de localización de la prenda; y ha dejado el punto a la deliberación de las partes. Su artículo 19 dispone: "Si se ha convenido un lugar en donde deba mantenerse la cosa empeñada [...]"; así que las partes de la convención prendaria pueden fijar un tal lugar mediante un especial pacto añadido a la convención; pero no están obligadas a hacerlo. Las posibilidades, por consiguiente, son tres:

i) Que guarden silencio sobre la materia; y en tal caso el pignorante, o el que tenga la cosa en su poder, son libres para localizarla dónde quieran, siempre que no cometan el delito previsto por el artículo $39 \mathrm{~N}^{\circ}$ 2: "El deudor prendario y el que tenga en su poder la cosa constituida en prenda en conformidad a esta ley que, defraudando al acreedor prendario, la [...] oculte, sustituya, traslade o disponga de ella”. Con la prevención, además, que si la pérdida o deterioro de la prenda puede ser causal y culpablemente conectada con algún traslado, el pignorante ha de responder al pignoratario por el perjuicio que le irrogó, de acuerdo con las reglas generales de la responsabilidad contractual.

ii) Que autoricen expresamente al pignorante a localizar la cosa donde quiera; y la situación, incluida la posibilidad del delito indicado, es igual a la del caso anterior.

${ }^{70}$ El trigo o el dinero, por ejemplo, son fungibles, así que la pérdida de las especies de granos de trigo o de los billetes, debidos en una cantidad determinada, que su deudor destinó al pago, no extingue la obligación y tal pérdida es a riesgo del mismo deudor; pero el trigo de silo $\mathrm{N}^{\mathrm{o}} 5$ o el millón de pesos guardado en la gaveta izquierda de tal escritorio son infungibles, de modo que la pérdida del trigo del silo $\mathrm{N}^{0} 5$ o del millón de la gaveta dicha sí extingue la respectiva obligación y es a cargo del acreedor (arg. ex artículo 1112 inciso $2^{\circ}$ del $C C$.). 
iii) Que fijen un "lugar en donde deba mantenerse la cosa empeñada"; y en tal caso el convenio debe ser cumplido de modo que, como añade el segmento primero del artículo 19: “[...] ésta [sc. la cosa empeñada] no podrá trasladarse".

El segmento final del mismo artículo señala la sanción de esta obligación de no hacer: "En caso de infracción a lo dispuesto precedentemente, el acreedor podrá exigir la inmediata realización de la prenda, considerándose la obligación caucionada como de plazo vencido". La obligación a término caucionada se acelera, es decir, vence su plazo, el deudor incurre en mora y entonces, o paga de inmediato aquella obligación, o el acreedor puede exigir la realización inmediata de la prenda, de acuerdo con las reglas generales de esta figura. La ley no distingue entre prenda constituida por el deudor o por un tercero; así que, en este último caso, aun cuando haya sido quien pignoró lo propio por deudas ajenas el que incumplió el pacto, igual se produce la aceleración en los términos dichos. Tampoco exige culpa o dolo en el traslado. Dice: "no podrá trasladarse"; no dice algo así como: "no podrá ser traslada por el constituyente". Emplea términos objetivos e impersonales ('se') que excluyen la alegación del caso fortuito o la fuerza mayor, e incluyen también el autotraslado de los semovientes, como cuando fue acordado que el ganado en prenda permaneciese en tal potrero, y las 224 reses saltan las vallas y pasan a otro o se dispersan en el campo; incluso, si un accidente rompió los cercados y quedó permitido el tránsito de las reses a diversos lugares. Esta interpretación en sentido objetivo de la obligación de no hacer de que tratamos, aparte de dimanar de los términos legales, está exigida por su propia naturaleza: la prenda sin desplazamiento se presta al fraude contra el acreedor por el fácil y natural transporte de los muebles que son su objeto, el cual puede diluir la garantía, máxime si se trata de fungibles, sólo desfungibilizados por su localización acordada previamente en la convención, efecto ése que el transporte extingue. Si se admite, pues, alegar ausencia de culpa o dolo en el transporte, se abre paso a la siempre fácil simulación de accidentes que consintieron el transporte.

La prueba de no haber habido culpa o dolo en el resultado evita, en cambio, la comisión del delito del artículo 39 No 2 ; y la indemnización de los perjuicios producidos al acreedor.

c) El artículo 19 prevé dos situaciones especiales. Puede acaecer que, habiéndose fijado en la convención un lugar donde deba mantenerse la cosa empeñada, algo de cualquier naturaleza haga necesario, provechoso o útil para la prenda o el pignorante su traslado a otro. La ley deja entregado el punto primeramente a la decisión de las partes de la convención: la prohibición de trasladar la prenda desde un lugar previamente convenido en la convención puede ser derogada o modificada "si el acreedor consiente", dice el artículo 19. La ley mira el punto desde la perspectiva del acreedor y 
asume que sea el deudor el interesado en el traslado. Para el caso de que el traslado sea beneficioso para la conservación de la prenda, y sólo para ese caso, se deja expedito que: "el tribunal competente del lugar de suscripción del contrato decrete su traslado [...] para su conservación”. Este recurso al tribunal en función de conservación de la cosa, puede ser intentado por el pignoratario si no obtuvo el consentimiento del acreedor; o por éste si aquél se muestra renuente a trasladarla por sí.

d) La sanción, consistente en la aceleración de la deuda en caso de contravenirse la localización fijada para la prenda rige también para el caso de que se la traslade desde el nuevo ligar consentido por el acreedor o fijado por el tribunal.

\section{Convenio de utilización de la cosa empeñada en una manera que se especifica}

El segundo segmento del artículo 19 dispone:
"Asimismo, si se ha convenido que la cosa empeñada se utilice de una forma especificada en el contrato, ésta no podrá utilizarse de forma distinta a lo pactado. Las prohibiciones anteriores rigen salvo que el acreedor consienta en ello o que el tribunal competente del lugar de suscripción del contrato decrete su [...] uso distinto para su conservación. En caso de infracción a lo dispuesto precedentemente, el acreedor podrá exigir la inmediata realización de la prenda, con- siderándose la obligación caucionada como de plazo vencido”.

Por regla general, el pignorante, en cuya tenencia permanece la cosa, la puede usar y gozar como quiera, con el límite de la culpa grave (artículo 18). La ley, sin embargo, prevé la posibilidad de que las partes, en derogación de la regla precedente, acuerden un específico uso o utilización aplicable a la cosa empeñada, y entonces el pignorante no puede utilizarla de manera distinta. Con posterioridad, el pignoratario puede autorizar cualquier uso distinto al convenido; y el tribunal competente que señala el artículo 19 está habilitado para decretar un uso también distinto al convenido, pero en función de la conservación de la cosa ${ }^{71}$. La transgresión de los usos especificados autoriza al acreedor para dar lugar a la aceleración de la deuda.

${ }^{71}$ La instancia al tribunal normalmente debería provenir del pignoratario, que es el interesado en conservar la cosa, cuando el uso convenido la amenace; y sólo raramente del pignorante, cuyo interés en cambiar el uso convenido por lo regular provendrá, no de la necesidad de conservar aquélla, sino de dedicarla a un uso no convenido para explotarla mejor. Así que, por lo ordinario, las demandas del pignoratario no han de ser atendidas, salvo el caso raro de obrar en interés de la conservación de la cosa empeñada. 


\section{Convenio relativo al modo de inspeccionar la prenda}

El artículo 20 dispone que el acreedor prendario tenga "derecho para inspeccionar en cualquier momento, por sí o por delegado, los efectos dados en prenda". Puede acaecer que estas visitas inspectivas irroguen "irrogaren daños o graves molestias" al pignorante; y para ese caso la ley autoriza que las partes convengan acerca del modo concreto en que deban ejecutarse tales visitas. Si no llegan a un acuerdo entonces dispone que "podrá el tribunal competente del lugar de suscripción del contrato de prenda regularlas con la sola audiencia de las partes".

El pacto de regulación de las visitas que la ley prevé como posible es más propio que tenga lugar en un momento posterior a la convención, cuando las visitas a que el acreedor de todos modos tiene derecho por concesión de la ley, empiecen a dañar o a molestar al pignorante. Mas, por supuesto, nada obsta a que las partes, ya en la convención, se adelanten a los hechos y provean a regular el modo de las visitas. Lo cual no impide que si con posterioridad igual se irroguen daños o molestias al pignorante, a falta de un nuevo acuerdo con el acreedor, aquél pueda recurrir al juez en demanda de regulación judicial.

\section{Convenio de poderse ceder con la prenda el crédito caucionado por ella}

a) De acuerdo con el artículo 1906 del CC.: "La cesión de un crédito comprende sus fianzas, privilegios e hipotecas [...]". Como se ve, la norma no menciona la prenda como comprendida en la cesión. Según algunos, empero la cesión igual las comprende ${ }^{72}$. El asunto no es tan claro. El Código sólo conoce la prenda con desplazamiento. Cuando se cede un crédito caucionado con una tal prenda, el tránsito de esta garantía y su privilegio desde el acreedor cedente al cesionario, que queda en calidad de nuevo acreedor, no puede ser ipso iure, porque previo es que la cosa pignorada misma sea entregada al cesionario para que actúe como garantía en su favor, a menos de construirse el caso como de prenda que no queda en manos del acreedor sino de un tercero, que sería el cedente (mientras no la entregue). Tal construcción ofrece el inconveniente de que el Código Civil no conoce la posibilidad de dejar la prenda en manos de un tercero designado de común acuerdo por las partes de la convención prendaria, que sí conoce, en cambio, el artículo 817 C. de Com. Además, la construcción en examen

${ }^{72}$ René Abeliuk Manasevich, Las obligaciones, $3^{\mathrm{a}}$ ed., Santiago, Editorial Jurídica de Chile, 1993, vol. II, N $\mathrm{N}^{\mathrm{O}} 1.063$, p. 874: "La solución [sc de comprender la prenda] tiene que ser la misma [sc. que en la hipoteca]". 
se sirve de una posibilidad que no es legal sino convencional, como es el acuerdo de nombrar un tercero, para producir un efecto legal, como es el del traspaso de la prenda al cesionario. No es inferior argumento en contra la inexistencia de un medio para obligar al cedente a entregar la prenda al cesionario, quien no podría perseguirla de sus manos, precisamente porque no dispone del derecho real mientras no la reciba. En fin, sostener que la garantía prendaria y su privilegio pasan al cesionario ya antes de que le sea entregada la cosa pignorada por el cedente, es sostener que el Código acepta una prenda sin desplazamiento al acreedor, lo que no parece posible sostener. De esta manera, es necesario rendirse a la evidencia de que la cesión no traspasa la garantía prendaria ni su privilegio al cesionario, sino desde que la cosa le sea entregada por el cedente.

b) Las dificultades para que la garantía se traspase al cesionario como efecto inmediato de la cesión misma no existen cuando aquélla consiste en una prenda sin desplazamiento, que se constituye convencional y no realmente. Tal es lo que explica que el artículo 1906 del $C C$., como vimos, haga operar legalmente el traslado de la hipoteca, que ofrece aquella misma característica.

La ley $\mathrm{N}^{0} 20.190$ obtuvo una consecuencia semejante; pero no igual. El traspaso de la garantía ofrecida por la prenda sin desplazamiento al cesionario del crédito caucionado exige unos requisitos que no existen para el traspaso de la hipoteca.

Dice el artículo 38:

"La cesión de créditos caucionados con esta prenda se sujetará a las reglas que correspondan a su naturaleza. Sin embargo, para que la cesión comprenda el derecho real de prenda, manteniendo la prenda la preferencia que gozaba en virtud del crédito cedido, en el Registro de Prendas sin Desplazamiento deben constar expresamente el crédito garantizado y la posibilidad de cesión de la prenda".

La ley exige, pues, dos requisitos.

i) El primero es que el crédito garantizado por la prenda (que es el que se cede) conste expresamente en el Registro de Prendas sin Desplazamiento. Esto, en realidad, significa:

i) que el crédito conste en la convención prendaria única manera de que después pueda hacérselo contar en el Registro y

ii) que la constancia del crédito es propiamente en la inscripción de la convención prendaria en el Registro.

Ahora bien, el requisito en examen implica que la ley autoriza el tránsito de la prenda y su privilegio sólo en el caso de haber sido constituida como garantía especial de una o varias obligaciones 
que se ceden. Dicho a la inversa, si la prenda fue constituida como garantía general, la cesión de alguna de los créditos incluidos en la generalidad caucionada no comprende en caso alguno la prenda ni su privilegio; lo cual es de toda lógica.

ii) El segundo requisito es que la posibilidad de poderse ceder el crédito también conste en el Registro, con las mismas advertencias que en el caso anterior, a saber, que esa autorización ya debe constar en la convención, como consecuencia de lo cual se la pueda hacer constar después en el Registro; y que la constancia de que aquí se trata es en la inscripción de aquella convención en el Registro.

Esta "posibilidad de cesión de la prenda" implica, en realidad, una legitimación de que goza el acreedor pignoratario, dada unilateralmente por el pignorante en la convención o acordada ahí mismo entre ambos o, bien, en un acto posterior (por cierto debidamente inscrito con ambas constancias). El traspaso de la prenda a un tercer cesionario no interesa o, incluso, puede perjudicar a su constituyente; y entonces se comprende que la ley haya exigido la autorización del pignorante para tal traspaso. Por lo mismo, la exigencia de publicidad de esa autorización, merced a su constancia en la inscripción de la convención en el Registro, no ha sido establecida en su beneficio, pues él no puede menos que conocer que autorizó al traspaso, 228 aun sin tal constancia, sino en beneficio de los terceros eventualmente cesionarios, que al verificar la existencia o la inexistencia de la constancia están en condiciones de saber que al aceptar la cesión de cierto crédito recibirán con ella la prenda que lo garantiza, o que no la recibirán.

c) Se observará que estos requisitos no son para que el acreedor pueda ceder el crédito, lo cual puede hacer libre de toda exigencia; sino, como dice la norma en examen, para que la cesión del crédito comprenda al derecho real de prenda que lo cauciona o, en términos más generales, para que la garantía y el privilegio ofrecidos por la prenda al crédito cedido pasen con éste al cesionario.

Supuesto, pues, que existan ambas constancias, el acreedor al ceder el crédito, lo cede con la prenda y su privilegio, que entonces pasan al cesionario, igual que a él pasa la hipoteca según el régimen civil, esto es, ipso iure. Si, por el contrario, no existen las dos constancias exigidas por la ley, aunque el acreedor igualmente pueda ceder su crédito, cuando lo haga no se traspasan la garantía prendaria ni su privilegio al cesionario, que se hace acreedor sin una ni otro.

Ahora bien, atendida la subsidiaridad de una prenda contraída como especial, cual es el caso, como vimos, producida la cesión del crédito sin traspaso de aquélla al cesionario, ya nada garantiza y no puede, por ende, subsistir; es decir, se extingue. Así que, en último término, es válido sostener que la cesión de un crédito garantizado con prenda sin desplazamiento 
especial, cuando no existan las dos constancias que la ley exige, extingue esa prenda.

Igual a como vimos acaece en los convenios de no repignoración, no enajenación o no imposición de gravámenes no prendarios, si el crédito o la autorización de ceder no constan en la convención, mal podrían constar en su inscripción en el Registro; y si, no obstante, constan, carecen de valor. Por el contrario, y a diferencia de aquellos convenios, supuesto que el crédito garantizado y la posibilidad de cesión de la prenda consten en la convención, cuando no constan en la inscripción, eso no crea problemas de oponibilidad a nadie. En tal caso, la prenda sin más no transita al cesionario con la cesión que de su crédito le haga el acreedor; y aquél tuvo que saberlo, precisamente porque no existían las constancias en la inscripción, por más que existieran en la convención.

d) A diferencia de cuanto acaece en otros pactos antes estudiados, en aquél que ahora examinamos las alternativas son sólo dos:

i) o las partes acordaron la posibilidad de ceder la prenda en la convención de la prenda (y se dejó constancia en la inscripción, etc.), y entonces la cesión del crédito acarrea la cesión o

ii) guardaron silencio las partes sobre el particular; y ahora es lo contrario, pues la cesión del crédito no importa la cesión de la prenda.

Una tercera opción, que sería pactar la imposibilidad de ceder la prenda (lo cual es perfectamente lícito), háyase o no dejado constancia en la inscripción, produce los mismos efectos que la segunda alternativa.

\section{Convenio de extensión de la responsabilidad del pignorante por la conservación de la cosa empeñada a la culpa leve}

El artículo 18 de la ley impone, en relación con la conservación de la cosa pignorada, la responsabilidad de depositario al pignorante.; y el artículo 2222 inciso $2^{\circ}$ del $C C$. sujeta al depositario a culpa grave o lata. De ésta, pues, responde el pignorante. Pero la citada norma del Código establece en su inciso $1^{\circ}$ : "La partes podrán estipular que el depositario responda de toda especie de culpa". La remisión del artículo 18 a la responsabilidad del depositario incluye la que las partes hayan pactado; así que consideramos como pacto posible en la convención prendaria, que el pignorante responda de toda clase de culpa; lo cual significa que responda, incluso, de la levísima. Por lo demás, establecer una responsabilidad más extensa que la derivada de culpa grave o lata siempre es posible merced a la libertad contractual.

Sin embargo, el mismo artículo 2222 del $C C$. añade en su inciso $3^{\circ}$ :

"Pero será responsable de la leve en los casos siguientes:/ 1. Si se ha ofrecido espontáneamente o ha pretendido se le prefiera a otra 
persona para depositario;/2. Si tiene algún interés personal en el depósito, sea porque se le permita usar de él en ciertos casos, sea porque se le conceda remuneración”.

Lo cual está dicho para el depositario; pero que podría alguien pretender aplicar al pignorante en virtud de la indiscriminada remisión del artículo 18 a la "responsabilidad de depositario" hecha para fijar la del pignorante.

La inaplicabilidad de este inciso $3^{\circ} \mathrm{y}$ sus dos números al pignorante, sin embargo, es más verdadera. Los casos de ambos números, pensados para el depósito, son situaciones de excepción en ese contrato, pues lo regular es que el depositario sea buscado por quien está deseoso de depositar; y que aquél carezca de todo interés en serlo. Para cuando fuere el excepcional caso contrario, la norma en examen le impone la culpa leve. Ahora bien, en la prenda, es normal que el pignorante ofrezca espontáneamente la garantía de algo suyo (en apoyo de su petición de crédito, por ejemplo); $\mathrm{y}$, sobre todo, que tenga interés personal en la prenda (para el mismo apoyo antes señalado, o porque desea aplacar a sus acreedores, etcétera). Así que lo excepcional en el depósito es casi regla en la prenda; y, en tales circunstancias, la remisión del artículo 18 de la ley a la "responsabilidad de depositario" sería a la "responsabilidad de depositario en el caso del 230 artículo 2222 inciso $3^{\circ}$ del $C C$.", es decir, a una parte excepcional de la norma que contiene esa responsabilidad, y no la parte de la misma que contiene la regla general. Por lo cual es mejor opinar que el mentado inciso $3^{\circ}$ no es aplicable jamás a la prenda, que opinar que es aplicable siempre, esto es, sólo él y no el resto de la norma.

\section{Convenio de no utilización, reemplazo, transformación o enajenación} de los componentes de un grupo de bienes de una misma clase o universalidades de hecho pignorados

Este convenio no es de aplicación general, mas únicamente relativo a un tipo de prenda caracterizada por su objeto.

El artículo 11 inciso $1^{\circ}$ de la ley, en efecto, considera la pignoración sin desplazamiento de grupos de bienes de una misma clase o universalidades de hecho, tales como existencias, inventarios, materias primas, productos elaborados o semielaborados o repuestos, o maquinarias, redes o sistemas; los componentes de los mismos podrán ser utilizados, reemplazados, transformados o enajenados, en todo o en parte. La misma norma autoriza que los componentes de tales grupos o universalidades puedan "ser utilizados, reemplazados, transformados o enajenados, en todo o en parte" y añade: "salvo pacto en contrario". Si los contratantes, en consecuencia, nada dicen sobre aquellas actividades aplicadas a los componentes, el 
pignorante puede libremente ejecutarlas; y lo mismo es si las autorizan expresamente en la convención. Pero también les queda expedido pactar no ejecutarlas o prohibir la ejecución de todas o algunas, respecto del todo o de una parte de los componentes. Con mayor razón podrían acordar que sean ejecutadas de alguna manera determinada. En todos los casos, la prenda "no podrá utilizarse de forma distinta a lo pactado". La sanción por el incumplimiento de tales pactos también se encuentra contenida en el artículo 19, con un régimen similar a aquél establecido para el caso de haberse pactado un lugar para la localización de la prenda; así que, en síntesis, de contravenirse el pacto, la deuda se acelera y el acreedor puede exigir la realización de la prenda. De todos modos, el acreedor puede después consentir en derogar o modificar el pacto; y el juez, pero sólo en función de conservar la prenda, es competente para autorizar un uso distinto al pactado.

\section{Convenio de no asignación de valor al conjunto de bienes pignorados}

Este convenio también atañe sólo a la prenda de grupos de bienes de la misma clase o universalidades de hecho a que se refiere el inciso $1^{\circ}$ del artículo 11 .

a) El mismo artículo, en su inciso $4^{\mathrm{o}}$, dispone:

"Cuando se pignoraren universalidades o grupos de bienes en la forma señalada en el inciso primero, el contrato de prenda deberá indicar el valor del conjunto de bienes sobre los que recaiga la prenda, salvo que las partes acuerden expresamente no asignarle un valor”.

La ley establece un deber consistente en indicar el valor del conjunto de bienes sobre los que recaiga la prenda, y se entiende que ello debe ser en la convención; así que se trata de un acuerdo especial contenido en él. La misma ley autoriza incumplir tal deber, pero sólo merced a un pacto expreso de no asignar valor al conjunto pignorado. Queda excluido, pues, guardar silencio sobre el valor. Así que, en el fondo, va otorgado escoger entre estos dos convenios en alternativa:

i) uno de fijación de valor, que puede asumir una forma expresa, consistente en acordar fijar un valor al conjunto pignorado seguido de su efectiva fijación, o tácita, que estriba en fijar directamente el valor al conjunto y

ii) el siempre expreso de no fijarle ninguno. La forma tácita de este mismo convenio, que consiste en nada decir sobre el valor, no está, como vimos, aceptada. 
b) Cuando las partes fijan un valor para el conjunto pignorado el inciso $4^{\mathrm{o}}$ del artículo 11 hace aplicable a esa prenda el artículo $1496 \mathrm{~N}^{\mathrm{O}} 2 \mathrm{del}$ $C C^{73}$, que establece:

"El pago de la obligación no puede exigirse antes de expirar el plazo, si no es:/ [...] 2. Al deudor cuyas cauciones, por hecho o culpa suya, se han extinguido o han disminuido considerablemente de valor. Pero en este caso el deudor podrá reclamar el beneficio del plazo, renovando o mejorando las cauciones".

Esta norma permite acelerar una obligación a plazo, cuando sus cauciones se extinguen o disminuyen considerablemente su valor. Si tal acaece a la prenda de un conjunto de bienes, cuyas partes le fijaron cierto valor en la convención, el acreedor puede hacer valer la aceleración. La aparentemente incompresible vinculación que el artículo 11 inciso $4^{\circ}$ establece entre la aplicabilidad del artículo $1496 \mathrm{~N}^{\circ} 2$ del CC. y la previa fijación de valor a la prenda -vinculación que no establece este último- tal vez se debe a la necesidad de tener un valor de referencia que permita verificar más fácil y directamente cuándo se produce la disminución considerable de valor de la prenda, y evite tener que recurrir a un tribunal para que él decida sobre 232 tal disminución, que, entre otros, obliga a convocar a peritos que comparen el valor original -que no es necesario hacer constar según el artículo $1496 \mathrm{~N}^{\mathrm{o}} 2$ del $C C$., como se hizo notar-y el valor actual supuestamente disminuido.

c) En la misma hipótesis de haber las partes fijado un valor al conjunto pignorado, tiene lugar un segundo efecto consistente en tornar en divisible la prenda de pleno Derecho sobre los bienes transformados a partir de los componentes del conjunto que se pignoró y de los productos elaborados con los mismos componentes, a que se refiere el inciso $2^{\circ}$ del artículo 11 .

Sustancialmente se trata de que, pignorado un conjunto de ciertas cosas que, merced a un normal proceso fabril, dan lugar a productos transformados o elaborados, éstos, por mandato del citado inciso $2^{\circ}$, quedan de pleno Derecho bajo prenda ${ }^{74}$. Pero esa norma no establece ningún límite a la extensión de la prenda legal que establece. Sin embargo, resulta ordi-

${ }^{73}$ Artículo 11 inciso $4^{\mathrm{a}}$ segundo segmento: "En este último caso, no será aplicable lo dispuesto en el artículo 1496, No 2 , del Código Civil y el contrato de prenda deberá señalar las particularidades tendientes a individualizar los bienes prendados, señalando si son fungibles o no, determinando en el primer caso su especie, cantidad, calidad, graduación y variedad".

${ }^{74}$ Artículo 11 inciso $2^{\circ}$ : "Los bienes transformados en virtud de lo dispuesto en el inciso anterior así como el producto elaborado con los componentes de dichas existencias, quedarán de pleno Derecho constituidos en prenda”. 
nario que el valor de los productos transformados o elaborados sea muy superior al de los elementos a partir de los cuales fue ejecutado el proceso de transformación o elaboración. Ahora bien, en virtud del principio de indivisibilidad de la prenda (artículo 2405 del $C C$.), es todo el conjunto de los productos transformados o elaborados el que empieza a quedar legalmente en prenda. Si llegare el caso de tener que ser ejecutada la caución, es todo ese conjunto, por ende, el que debe ser vendido. Sin embargo, la asignación de valor al conjunto original en la convención prendaria impone un límite a esta prenda legal sobrevenida, la cual, pues, extendiéndose sobre los productos transformados o elaborados hasta concurrencia del valor inicialmente asignado, sólo puede ser realizada sobre ellos en la medida suficiente para el pago de todos los rubros que la realización debe cubrir, vale decir, el total del monto del crédito, sus intereses y los gastos y costas, si los hubiere (artículo 15).

d) Si las partes, en cambio, acuerdan no fijar un valor al conjunto pignorado la primera consecuencia de tal pacto es la inaplicabilidad del artículo $1496 \mathrm{~N}^{\mathrm{o}} 2$ del $C C$. a la prenda contraída, de modo que el pignorante no está sujeto a la carga de no disminuir considerablemente, por hecho o culpa suya, el valor de lo pignorado; y puede proceder a causar impunemente una tal disminución. A salvo, sin embargo, que tenga prohibido, por pacto prendario, utilizar, reemplazar, transformar o enajenar los componentes del conjunto pignorado (artículo 11 inciso $1^{\circ}$ ) o, bien, que haya pactado no utilizarlos sino de una manera especificada en dicha convención (artículo 19); porque la contravención de estos pactos, haya o no disminución en el valor de lo pignorado, le acarrean la caducidad del plazo de su deuda, no por aplicación, ciertamente, del artículo 1496 $\mathrm{N}^{\mathrm{o}} 2$ del $C C$., mas como consecuencia directamente prevista en la nueva ley misma.

La ley parece creer que no habiéndose fijado valor al conjunto, no es posible o es difícil saber si hubo disminución considerablemente de valor; y por ello hace inaplicable el citado artículo $1496 \mathrm{~N}^{\circ} 2$ del $C C$.

e) El segundo efecto del pacto de no fijación de valor es la ilimitación de la prenda de pleno Derecho establecida por el inciso $2^{\circ}$ del artículo 11 sobre los bienes transformados a partir de los componentes del conjunto que se pignoró y de los productos elaborados con los mismos componentes. En el caso, recobra su plena vigencia el principio de indivisibilidad de la prenda; y es todo el conjunto de bienes transformados y productos elaborados el que resulta bajo prenda legal.

f) Aunque la ley no lo consiente, puede ocurrir que las partes de la convención prendaria no fijen valor al conjunto pignorado ni acuerden no fijarlo; o sea, que guarden silencio sobre el punto. Este silencio es una transgresión del mandato legal, que ordena fijar el valor (“deberán” dice) 
salvo que opten por acordar no hacerlo. Tal transgresión tiene que producir algún efecto; pero la ley no lo indica. En otro lugar, hemos opinado que tal efecto debe ser la conversión de la convención de prenda sin desplazamiento sobre grupos de bienes o universalidades de hecho, regida por el artículo 11, en convención de prenda sin desplazamiento general, es decir, no regida especialmente por aquél, teniendo presente que el artículo 3, el cual gobierna la generalidad de estos contratos, no exige la fijación del valor ni el pacto de no fijarlo. Pero esta conversión entraña un riesgo: como el artículo $3 \mathrm{~N}^{\mathrm{O}} 3$ obliga a individualizar o caracterizar las cosas empeñadas, no rigiendo el artículo 11, que sólo obliga a individualizar o caracterizar el conjunto como tal y no a sus componentes, la individualización o caracterización que por aplicación del articulo $3 \mathrm{~N}^{0} 3$ procedería debe ser relativa precisamente a los elementos contenidos en el conjunto que se había pignorado en vano de acuerdo con el artículo 11; así que cuando, de alguna manera, no aparezcan individualizados o caracterizados tales elementos, ahora la convención es nula ${ }^{75}$.

\section{BiBLIOGRAFÍA}

234 Abeliuk Manasevich, René, Las obligaciones, $3^{a}$ ed., Santiago, Editorial Jurídica de Chile, 1993, vol. II.

Carrasco Perera, Ángel y otros, Tratado de los derechos de garantía, Cizur Menor, Navarra, Aranzadi, 2002.

Claro Solar, Luis, Explicaciones de Derecho civil chileno y comparado, reimpresión facsimilar de la edición de 1936, Santiago, Editorial Jurídica de Chile, 1992, vol. $\mathrm{x}$ : De las obligaciones, 1.

Corral Talciani, Hernán, "La definición de contrato en el Código Civil chileno y su recepción doctrinal. Comparación con el sistema francés", en Hernán Corral Talciani - Guillermo Acuña Sboccia (editores), Derecho de los contratos. Estudios sobre temas de actualidad, Santiago, Universidad de los Andes, Cuadernos de Extensión Jurídica, № 6, 2002.

Elorriaga De Bonis, Fabián, "La prenda de créditos nominativos en la nueva normativa de la prenda sin desplazamiento", en Carlos PizArRo Wilson (coordinador), Estudios de Derecho civil IV. Jornadas Nacionales de Derecho Civil, Olmué, 2008, Santiago, LegalPublishing, 2009.

GuZMán Brito, Alejandro, "La pignoración de grupos de bienes de una misma clase o universalidades de hecho en la nueva Ley de prenda sin desplazamiento", en Revista de Derecho de la Pontificia Universidad Católica de Valparaíso, $\mathrm{N}^{\circ}$ 30, Valparaíso, $1^{\text {er }}$ semestre de 2008.

${ }^{75}$ Véase: GuZmán BRito (n. 45), p. 132. 
GuZmán Brito, Alejandro, "La prenda sin desplazamiento de cosas corporales e incorporales futuras", en Revista de Derecho de la Pontificia Universidad Católica de Valparaíso, No 31, Valparaíso, $2^{\circ}$ semestre de 2008.

GuZMÁn BRITO, Alejandro, "La prenda sin desplazamiento de inmuebles por adherencia o destinación y su concurrencia con otras prendas o con una hipoteca”, en Homenaje al profesor Pablo Rodríguez Grez, a la fecha de esta publicación en prensa.

GuZmán Brito, Alejandro, "Las prendas ordinaria y sin desplazamiento de la Ley No 20.190 recaídas en cosa ajena”, en Fabricio Mantilla Espinoza - Carlos Pizarro Wilson (coordinadores), Estudios de Derecho privado en homenaje a Christian Larroumet, Santiago - Bogotá, Fundación Fernando Fueyo - Universidad Diego Portales - Universidad del Rosario, 2008.

Guzmán Brito, Alejandro, De las donaciones entre vivos. Conceptos y tipos, Santiago, Lexis Nexis [hoy LegalPublishing], 2005.

Historia de la Ley $N^{0} 20.190$ (Biblioteca del Congreso Nacional, 5 de junio de 2007) [visible en: http://www.bcn.cl/histley/lfs/hdl-20190/HL20190.pdf].

López SANTA MaríA, Jorge, "Informe sobre contrato de línea de crédito. Cláusula de garantía general prendaria. Distinción entre contratos civiles y contratos mercantiles", en Revista de Derecho de la Universidad Católica de Valparaíso, N ${ }^{\circ}$ 4, Valparaíso, 1980.

López Santa María, Jorge, Los contratos. Parte general, $4^{\mathrm{a}}$ ed., Santiago, Editorial Jurídica de Chile, 2005, vol. I.

Marchese, Angelo - Forradellas, Joaquín, Diccionario de retórica, crítica y terminología literaria, $4^{\mathrm{a}}$ ed., Barcelona, Ariel, 1994.

"Mensaje presidencial", en Historia de la ley $N^{0}$ 20.190. Biblioteca del Congreso Nacional, 5 de junio de 2007, en: http://www.bcn.cl/histley/lfs/hdl-20190/ HL20190.pdf

Mery Berisso, Rafael, Derecho hipotecario. Estudio de Derecho civil chileno y comparado, Santiago, Editorial Jurídica de Chile, 1958.

Pisani, Cinzia, "Pegno omnibus", en Cendon, Paolo (a cura di), Il Diritto privato nella giurisprudenza. I Nuovi contratti nella prassi civile e commerciali, Torino, UTET, 2004, vol. XIX: Garanzie.

Pothier, Robert-Joseph, Traité des obligations, en Euvres de Pothier, Paris, Bugnet editor, Cosse et Marchal - H. Plon, 1871, vol. x.

"Primer informe de la Comisión de Hacienda de la Cámara de Diputado", en Historia de la ley $N^{0}$ 20.190. Biblioteca del Congreso Nacional, 5 de junio de 2007, en: http://www.bcn.cl/histley/lfs/hdl-20190/HL20190.pdf

Somarriva Undurraga, Manuel, Tratado de las cauciones, $2^{\mathrm{a}}$ ed., Santiago, Contable Chilena, 1981.

UGarte Godoy, José Joaquín, "La nulidad de la cláusula de garantía general hipotecaria", en Revista de Derecho y Jurisprudencia No 88, Santiago, 1991, Fasc. $3^{\circ}$. 
Veiga Copo, Abel, "Prenda 'omnibus', prenda rotativa de acciones y garantía flotante", en Revista de Derecho Bancario y Bursátil, año 20, No 82, Madrid, 2001. Vergilius, Georgica. 